\title{
INDULTOS PARTICULARES DURANTE EL DIRECTORIO MILITAR DE PRIMO DE RIVERA (1923-1925)
}

\section{INDIVIDUAL PARDONS DURING THE MILITARY DIRECTORY OF PRIMO DE RIVERA (1923-1925)}

\author{
Miguel Ángel Morales Payán \\ Universidad de Almeria
}

SUMARIO: I. INTRODUCCIÓN. II. EL DIRECTORIO MILITAR. III. INDULTOS PARTICULARES. IV. FICHAS.

Resumen: La concesión de indultos ha sido una práctica tradicionalmente asociada a la monarquía. En la etapa contemporánea, en España, todos los textos constitucionales decimonónicos así lo establecían. Las razones por las que se concede esta gracia son muy variadas: desde cuestiones de politica general, pasando por razones de política criminal, como beneficio penitenciario o como correctivo de la función juzgadora. En el presente artículo se trata de analizar, con arreglo a los datos que nos aporta la Gaceta de Madrid (BOE), los indultos particulares concedidos por Alfonso XIII durante los poco más de dos años que duró el Directorio Militar de Primo de Rivera, un período en el que la vigencia de la Constitución de 1876 estaba suspendida.

\begin{abstract}
The granting of pardons has been a practice traditionally associated with the monarchy. In the contemporary era, in Spain, all nineteenth century constitucional texts established it. The reasons for granting this privilege are varied: from general policy issues, through criminal policy reasons, as a penitentiary benefit or as a corrective of the judging function. This article tries to analyze, according to the data provided by the Gaceta de Madrid (BOE), the particular pardons granted by Alfonso XIII, during Military Directory of Primo de Rivera (little more than two years), period in wich the Constitution of 1876 was suspended.
\end{abstract}

Palabras clave: Alfonso XIII; Directorio Militar; Amnistia; Indulto.

Key Words: Alfonso XIII; Military Directory; Amnesty; Pardon.

\section{INTRODUCCIÓN}

De origen muy antiguo, desde hace milenio y medio, en nuestro país, el derecho de gracia, esa posibilidad de perdonar a quien delinque (con mayor o menor extensión, más o menos requisitos y de formas muy diversas), ha sido tradicionalmente asociado ineludiblemente a la monarquía ${ }^{1}$. Dentro de esa

\footnotetext{
1 Marquina y Kindelán, C., Breves consideraciones sobre el derecho de gracia, Madrid, 1900, p. 20: "La ley penal es la primera y la más indispensable de las leyes de todo organismo humano, hasta tal punto, que no puede concebirse, ni ha existido jamás sociedad alguna, sin sanción penal y sin los medios de hacer efectiva y de anular esa misma sanción, impuesta por el jefe de la tribu, pueblo o sociedad...". Las fuentes suelen relacionar directamente a la monarquía con el
} 
amplia y magnánima prerrogativa de clemencia sobresalen el indulto y la amnistía. Ambos tienen como común denominador el principio de que, dado que el Estado monopoliza el ius puniendi, el derecho a castigar, se puede permitir ciertas aquiescencias, como el exigir o no el cumplimiento de las penas (de modo total o parcial) o, incluso, su canje o desaparición ${ }^{2}$. Comparten, además, como destaca Requejo Pagés, su "condición de institutos a cuyo través se excepciona la legalidad"3.

La amnistía se tiene por "una suerte de derogación retroactiva que puede afectar bien a la norma que califica a un acto como ilicito, bien a la que dispone como consecuencia de la verificación de un acto así calificado- la imposición de una sanción". En cambio, el indulto, se considera que "no actúa sobre la realidad jurídica de un acto calificado como ilícito, ni afecta a la ilicitud en cuanto tal, sino que opera sobre su sanción, sea para excluirla sea mitigarla. Así las cosas, el indulto presupone siempre un ilicito que, a diferencia de la que puede suceder con la amnistía, permanece incólume". Prosigue el autor citado subrayando que "con él no se censura la norma calificadora de un acto como ilícito; simplemente

'perdón', la 'gracia', la 'piedad', la 'merced', la 'misericordia', la 'indulgencia', la 'remisión', la 'abolición', etc. Veánse, al respecto, Rodríguez Flores, I., El perdón real en Castilla (siglos XIII-XVIII), Salamanca, 1971, especialmente pp. 21-44. También, Tomás y Valiente, F., “El perdón de la parte ofendida en el derecho penal castellano (siglos XVI, XVII y XVIII)" en Anuario de Historia del Derecho Español 31 (1961), pp. 55-114; Bermejo Cabrero, J.L., Poder politico y administración de justicia en la España de los Austrias, Madrid, 2005, especialmente pp. 317 y ss.; Hespanha, A.M., "Da 'Iustitia' a 'disciplina'. Textos, poder e politica penal no antigo Regime" en Anuario de Historia del Derecho Español 57 (1987), pp. 493-578; Dios, S. de, Merced y Patronazgo Real. La Cámara de Castilla entre 1474-1530, Madrid, 1993.

\footnotetext{
2 Según el Diccionario judicial que contiene la explicación y significación de las voces más en uso en los tribunales de justicia por D.J.F.A., Madrid, Imprenta de D. Miguel de Burgos, Setiembre de 1831, pp. 142-143, indulto es: "Gracia o privilegio concedido a alguno para que pueda hacer lo que sin él no podría. Gracia por la cual el superior remite la pena, o exceptúa y exime a alguno de la ley y de cualquier otra obligación". Villalba, Hervás, L.M., "La gracia de indulto ¿Procede aplicarla por los Tribunales en causa pendiente en virtud del desistimiento del Ministerio fiscal, cuando se opone la parte querellante?" en Revista General de Legislación y Jurisprudencia 85 (1894), p. 281, lo define como: "la remisión de la pena que un delincuente hubiere merecido por su delito" mientras que, para Martinez Alcubilla M., Diccionario de la administración española, peninsular y ultramarina. Compilación ilustrada de la novísima legislación de España en todos los ramos de la administración, $2^{\text {a }}$ ed., Madrid, 1868, voz 'indulto', es la "Condonación o remisión de la pena que un delincuente merece por su delito. Entre las prerrogativas que nuestra Constitución señala al Rey se encuentra la de indultar a los delincuentes con arreglo a las leyes. Ténganse presentes los arts. 45 y 50 del Código penal respecto de los efectos de los indultos". En la misma línea, Langle, E., Código penal de 17 de junio de 1870, Madrid, 1915, p. 210, considera que se trata de "una institución mediante la cual se remite toda la condena, o toda la pena principal, o parte de ella, o alguna si son varias, o se conmuta la impuesta por otra de la misma escala. Corresponde concederlo al Rey, con arreglo a las leyes, según expresa el núm. $3^{\circ}$ del artículo 54 de la Constitución". Véanse además, entre otros, Pacheco, J.F., Estudios de Derecho penal. Lecciones pronunciadas en el Ateneo de Madrid, I, Madrid, 1842; Diego Madrazo, S., De la gracia de indulto, Memoria leida por el Sr. D..., Madrid, Imprenta de Eduardo Martínez García, 1874; Arenal, C., "El derecho de gracia ante la justicia” en RGLJ 54 (1879), pp., 595-621; Montes, J., La pena de muerte y el derecho de indulto, Madrid, 1897; Sobremonte Martinez, J. E., Indultos y amnistia, Valencia, 1980; Herrero Bernabé, I., El Derecho de gracia: indultos, tesis doctoral, Madrid, UNED, 2012; Morales Payán, M.A., "Judicial Independence in the middle of the 19th century: from theory to practice” en Pérez Juan, J.A. (hg), Gerichtsverfassung und Verfahren im 19. Jahrhundert, Regensburg, 2018, pp., 31-74, especialmente, 59 y ss.
}

3 Requejo Pagés, "Amnistia e indulto en el constitucionalismo histórico español" en Historia Constitucional. Revista electrónica, 2 (2001), p. 82. 
se excepciona su aplicación en un caso concreto (indulto particular) o para una pluralidad de personas o supuestos (indulto general)". Esto es, una de las grandes diferencias entre ambas instituciones es que mientras que con la amnistía es cierto que se puede modificar o anular una decisión judicial, pero, porque quien crea normas (legislativo/ejecutivo), se enmienda asi mismo con posterioridad, con el indulto, en cambio, hay una notable injerencia (del ejecutivo normalmente) en la actuación de los tribunales, dado que se alteran unas decisiones ya tomadas, adulterando las consecuencias de las sentencias ${ }^{4}$.

De ahí que la amnistía, tradicionalmente enmarcada en un ámbito genuinamente político, históricamente, no haya causado tanta controversia como el indulto. Emilio Bravo, eminente jurista decimonónico, publicó una monografia sobre la cuestión en la que, al hilo de explicar las diferencias entre amnistía e indulto, subrayaba que amnistía, etimológicamente, era un término procedente del griego que significa olvido. Dicho de forma más simple, se ha de hablar de amnistía al tratar de hacer borrón y cuenta nueva cuando las circunstancias políticas así lo aconsejan ${ }^{5}$. Insistía en que esta figura responde únicamente a razones de conveniencia politica. Del indulto, en cambio, resaltaba la diferencia entre el particular y el general ${ }^{6}$. Precisamente destacaba que la amnistía comparte con el indulto general el hecho de que se conceda a una colectividad de personas, pero se diferencia en que mientras ésta se emplea en el contexto de delitos de un claro perfil político el indulto se hace para los comunes ${ }^{7}$. También los motivos que justifican su concesión en uno y otro caso son diferentes, pues en

4 Para Elorza Aristorena, J., "Consideraciones histórico doctrinales sobre la ley de indulto de 18 de junio de 1870", conferencia pronunciada con motivo del curso monográfico sobre el Centenario de una obra legislativa, Valencia, 1972, p. 180, la diferencia más significativa entre una y otro es que mientras "la amnistía es un acto de alta politica, realizado con fines de pacificación social" el indulto es "un expediente más judicial que politico".

5 Según Bravo, E., La gracia del indulto, Madrid, 1889, pp. 27 y ss., la amnistía arranca de una "ley dada por Thrasibulo con el fin de asegurar la paz después de una de las más terribles alteraciones de Grecia. Ningún poder vencedor, por fuerte y severo que haya sido, desdeñó jamás esta medida de generosidad y perdón que lleva en sí en admirable consorcio la clemencia y la previsión. Ella desarma comúnmente las actitudes de represalia en el ánimo de los vencidos, extingue el peligroso rescoldo de un incendio, no totalmente apagado, y hace posible que hombres dignos, envueltos en las desgracias o en la emigración, recobren el perdido hogar y el albedrio, y aún el que lleguen a prestar su concurso al orden de cosas establecido por la victoria". En cambio, para Cadalso, F., La libertad condicional, el indulto y la amnistia, Madrid, 1921, p. 195 (al que sigue Linde Paniagua, E., Amnistia e indulto en España, Madrid, 1976, p. 27), el origen hay que remontarlo a los Libros Sagrados de la India.

${ }^{6}$ La Ley de 18 de junio de 1870 en su capítulo II trata De las clases y efectos del indulto. En ese sentido, sólo distingue entre el indulto total o el parcial (art. 4).

7 Bravo, E., La gracia del indulto, op. cit., pp. 24-25: "En esta clase de gracia ha habido siempre limitaciones y reglas. No solía comprender a los reos de crimen llamados en la antigua clasificación de lesa majestad divina o humana, de alevosia, de homicidio de sacerdote, de fabricación de falsa moneda, de incendio, de falsedad, de robo, de cohecho y baratería, de resistencia a la justicia, de malversación a la Hacienda pública, de extracción de cosas prohibidas a naciones enemigas, de sodomía, lenocinio, desafio, rapto y violencia de mujeres, como puede verse en las leyes $1^{\mathrm{a}}, 4^{\mathrm{a}}$ y $5^{\mathrm{a}}$ notas 1 y 9, tít. 42 libro 12 de la Novísima Recopilación, Reales Cédulas de 17 de Octubre de 1771 y 22 de Diciembre de 1795. Esta distinción ha desaparecido ya, sustituyéndose con otro criterio. Comúnmente se otorga el perdón a los sentenciados a penas correccionales, entendiéndose total, sobre todo, si fueren de arresto mayor, haciéndose rebaja en las demás. Se excluyen siempre de la gracia los delitos privados. En los de imprenta no hay otra excepción que los de injuria y calumnia generales". 
el caso del indulto se obvian los condicionantes politicos y si bien se recurre a la clemencia como último recurso, en el siglo XIX era habitual hacerlos coincidir con hechos o acontecimientos de gran notoriedad y algarabía en el país, siendo especialmente relevantes, en la España de la época, bien los relacionados directamente con el devenir de la monarquía (el acceso al trono de un nuevo rey, su casamiento, el nacimiento de un heredero...) bien los relacionados con tradiciones religiosas (consagración del día de la cruz, privilegios concedidos a cofradias religiosas...).

La normativa reguladora de la concesión de indultos podría calificarse de antiquísima, compleja e incompleta. En este sentido, se llega al último tercio del siglo XIX y no hay una única norma que haga una regulación integral de esta institución hasta la aparición en escena, tras diversos intentos fallidos y respondiendo a una apabullante demanda social, de la Ley provisional estableciendo reglas para el ejercicio de la gracia de indulto en $1870^{8}$. Hasta ese momento hay que recurrir a fuentes como el Fuero Juzgo, el Fuero Real, las Leyes del Estilo, las Partidas, el Ordenamiento de Briviesca, las Ordenanzas Reales de Castilla, la Nueva Recopilación, la Novísima Recopilación y un largo etcétera de disposiciones decimonónicas (reglamentos, reales decretos, reales órdenes.... $)^{9}$ generadores de un espeso entramado que dificultaban la comprensión de su marco regulador. Los textos constitucionales que se iban sucediendo a lo largo del siglos XIX se limitaban únicamente a reconocer su existencia y residenciarla en el monarca ${ }^{10}$.

8 Con fecha de 18 de junio y el refrendo de Eugenio Montero Ríos, Ministro de Gracia y Justicia, consta de 32 artículos agrupados en tres capitulos: De los que pueden ser indultados, De las clases y efectos de los indultos y Del procedimiento para solicitar y conceder la gracia del indulto.

9 Véase al respecto Herrero Bernabé, I., “Antecedentes históricos del indulto" en Revista de Derecho UNED 10 (2012), pp. 687-709.

10 Así, según el Estatuto de Bayona (art. 112) el derecho de perdonar "pertenecerá solamente al Rey y le ejercerá oyendo al ministro de Justicia...". Para la Constitución de 1812 (art. 171): “... al Rey... le corresponde como principales las facultades siguientes: ... Decimatercia. Indultar a los delincuentes, con arreglo a las leyes". Esta fórmula se repite en la 1837 (art. 47), 1845 (art. 45) y 1876 (art. 54) donde entre las prerrogativas que la Constitución señala al Rey "le corresponde: .... 3. Indultar a los delincuentes, con arreglo a las leyes". Cambia, sin embargo, en la de 1869 (art. 74) pues el Rey "necesita estar autorizado por una ley especial: ... 5. Para conceder amnistías e indultos generales" y en el proyecto de Constitución Federal de 1873 donde se le atribuye al Presidente de la República la facultad de conceder indultos (art. 82). En el ámbito de los códigos penales el Código Penal de 1822 le dedica quince artículos colocados en el Capítulo X (De los indultos) del Título Preliminar. Como recuerda Elorza Aristorena, J., "Consideraciones histórico doctrinales sobre la ley de indulto de 18 de junio de 1870”, op. cit., p. 197, aunque es minuciosamente regulado por esta disposición, siguiendo el dictado constitucional, la Comisión que preparó el Código "no pudo ocultar que veía con malos ojos el indulto, pues en la exposición que acompaña al proyecto presentado, reproduce los argumentos contrarios a la prerrogativa Real...". Los códigos de 1848, 50 y 70 lo regularán de una manera dispersa y fragmentaria (habitualmente al tratar de los efectos de las penas). Marquina y Kindelán, C., Breves consideraciones sobre el derecho de gracia, op. cit., p. 20: "Cuando a principios del siglo actual se implantó en casi todos los pueblos de Europa la Monarquía Constitucional, y con ella la división de poderes, se reconoció a uno de ellos el derecho de administrar justicia en nombre del Rey y el de conocer también de las apelaciones a que podian dar lugar los fallos de los Tribunales inferiores, quedando reservada al Rey, como derecho de soberanía, la prerrogativa de indulto...". 
En la práctica, tal maremagno facilitaba constantes abusos en su concesión que exasperaban a buena parte de la sociedad ${ }^{11}$.

La ley de 1870 pretendia conseguir, al menos, dos objetivos: por un lado, acabar con la controversia de si el indulto debía permanecer o desterrarse por completo de nuestro ordenamiento jurídico; y, por otro, asegurada no sólo su presencia sino también su dependencia real, tratar de establecer un escenario legal claro y diáfano que alejase la controversia en su concesión.

\section{EL DIRECTORIO MILITAR}

Entramos en la tercera década del siglo XX y la complejidad de los acontecimientos políticos provocan la aparición en escena de Miguel Primo de Rivera que, con la aquiescencia de Alfonso XIII, toma las riendas del gobierno suspendiendo la aplicación de la vigente Constitución de $1876^{12}$. Cronológicamente la dictadura de Primo de Rivera se extiende del 13 de septiembre de 1923 al 28 de enero de $1930^{13}$. En estos poco más de seis años y cuatro meses de gobierno habitualmente se distinguen dos fases: la llamada del

${ }^{11}$ Las discusiones entre detractores (admitir el indulto es reconocer la imperfección e injusticia del sistema legal) y partidarios (es un remedio para corregir situaciones injustas ante la imposibilidad del legislador de preverlo todo) del derecho de gracia ya venian de antiguo aunque a lo largo del XIX en nuestro país adquieren un auge inusitado, derivado, sin duda, de la agitación politica existente y el uso constante (o mal uso incluso) que, en este revuelto contexto, hicieron los distintos monarca y gobiernos. Sirvan como referencia el hecho de que la Revista General de Legislación y Jurisprudencia en su número 14 del año 1859 (pp. 92-105) denunciaba la inquietud que la desafortunada utilización de la gracia regia estaba generando en la sociedad: "la cuestión de indultos ha llamado recientemente la atención del público, no tanto por el número de los concedidos como por la clase de las personas y por la naturaleza de los delitos en que se ha otorgado la Real gracia”. Igualmente, la sexta edición del Diccionario de Martínez Alcubilla se seguía quejando del abuso en la concesión de los indultos. Voz 'indulto': “... Creencia tan errónea está autorizada en nuestro país por la frecuencia con que se conceden indultos generales, verdaderas amnistías, que atajan la acción de los Tribunales y escarnecen la fuerza imperativa de sus fallos, y que se inspiran frecuentemente en el propósito de complacer a fuerzas políticas o sociales que exigen el perdón y no en el designio puro de dulcificar la situación de los que han de resultar favorecidos o de redimir la pena a los arrepentidos de su delito...". También Dorado Montero, El derecho protector de los criminales, II, Madrid, 1915, p. 449: "Del derecho de indultar a los delincuentes 'con arreglo a las leyes', que corresponde al Jefe del Estado en la forma que acabamos de decir, se puede abusar y se abusa a menudo...". Igualmente, Montes, J., La pena de muerte y el derecho de indulto, op. cit., p. 225: "Que en el ejercicio del derecho de gracia se cometen y se han cometido siempre abusos, no hay necesidad alguna de demostrarlo...". Incluso, una vez admitida su existencia, los consiguientes abusos y la necesidad de limitarlos, también se discutía en quién debía recaer la responsabilidad de otorgarlos y con arreglo a qué criterios.

12 La ley del indulto, promulgada como provisional, llevaba más de 50 años rigiendo; y eso a pesar de que, no habian transcurrido ni tres años desde su promulgación, cuando, en plena efervescencia republicana, la disposición normativa queda derogada al decretar las Cortes Constituyentes, por medio de una Ley promulgada el 9 de agosto de 1873, la abolición de la gracia de indulto para todos los delitos, a excepción de los de muerte. Sin embargo, su apuesta duró poco, pues por medio del Decreto de 12 de enero de 1874 se restablecía la Ley provisional. Sobre su devenir puede verse Herrero Bernabé, I., El Derecho de gracia: indultos, op. cit., pp. 33 y ss.

13 Tamames, R., Ni Mussolini ni Franco: la dictadura de Primo de Rivera y su tiempo, Barcelona, 2008, p. 194: "Desde el enfoque de su evolución, la Dictadura pasó por dos etapas bien diferenciadas, la primera, el régimen del directorio militar (13 de septiembre de $1923-2$ de diciembre de 1925)...”. 
Directorio militar ${ }^{14}$ y la del Directorio civil ${ }^{15}$. La primera, objeto de este trabajo, dura hasta el 2 de diciembre de 1925.

Los autores que han trabajado esta época suelen coincidir, aunque con enfoques diferenciados en ocasiones, en una serie de factores que precipitaron la solución dictatorial ${ }^{16}$. Unos de carácter externo, tales como la consolidación de la Revolución Rusa o el surgimiento del fascismo en Italia, por ejemplo, y otros internos como el colapso del sistema de la regeneración, la crisis económica y social derivada de la finalización de la $1^{\mathrm{a}}$ Guerra mundial, el problema de Marruecos o el terrorismo, por sólo citar algunos ${ }^{17}$. Convienen, además, en destacar sus fracasos (fiasco económico, frustración institucional, rebeliones en el seno del propio ejército, alejamiento de numerosos sectores de la sociedad, etc.) pero también algún resultado que tradicionalmente se ha tenido por positivo, como la finalización de la guerra con nuestro vecino norteafricano $\mathrm{y}$, de modo especial, en el campo del orden público ${ }^{18}$. En este sentido, no se han de perder de

14 Cassasas Ymbert, J., La dictadura de Primo de Rivera (1923-1930). Textos, Barcelona, 1983, p. 32 "E1 Directorio Militar se definió a sí mismo como una solución a '90 días vista"; Ben-Ami, S., La dictadura de Primo de Rivera. 1923-1930, Barcelona, 1983, p. 67: "El Directorio militar que gobernó el país hasta diciembre de 1925 era un dispositivo operativo hondamente arraigado en los regímenes militares 'de paréntesis', que se esfuerzan por 'poner orden' y luego devuelven el ejército a los cuarteles”. Ballbé, M., Orden público y militarismo en la España constitucional (18121983), Madrid, 1983, p. 307: "El Directorio militar, mediante Circular de 15 de septiembre de 1923, suspende las garantías constitucionales, disuelve las Cortes y extiende el estado de guerra proclamado en las regiones sublevadas. En otras palabras: en principio se mantiene formalmente la Constitución de 1876 y se considera la situación como un mero estado de excepción transitorio. Paradójicamente el régimen terminará de igual forma que los primeros años de su comienzo".

15 González Martínez, C., "La Dictadura de Primo de Rivera: una propuesta de análisis" en Anales de Historia Contemporánea 16 (2000), pp. 343-344: "Conseguida la pacificación de Marruecos, desaparecidos los problemas de orden público y las huelgas, la Dictadura durante esta primera etapa se legitimó por sus hechos: los gobernados, de alguna manera, le reconocían su derecho a gobernar. La Dictadura inicia entonces una segunda etapa cuya tarea principal es la consolidación del régimen mediante un partido único y una nueva constitución. Esta nueva etapa del régimen, desde diciembre de 1925 hasta la dimisión de Primo de Rivera, se caracterizó por una menor presencia del ejército en los cargos politicos, lo que resulta evidente en el nuevo Directorio Civil encargado del gobierno, y por el planteamiento de objetivos más amplios de desarrollo económico, reforma social y reconstrucción politica para los que se requería mayor intervención y penetración del régimen en la sociedad. Fue entonces cuando la Dictadura realizó una ruptura definitiva con el parlamentarismo liberal anterior para intentar consolidar en España un régimen autoritario y corporativo".

16 Gózalez-Ruano, C., Quién fue.. El General Primo de Rivera, Barcelona, 1959, p. 62: "Don Alejandro Lerroux, en una frase no ciertamente poética, pero sí expresiva, dijo, cuando tuvo noticia del levantamiento militar: 'El grano habia de reventar algún dia”.

17 De un modo genérico, Cambó, F., Las dictaduras, Madrid-Barcelona, 1929, en pp. 69 y ss., enumera como causas que provocan el advenimiento de las dictaduras en Europa, entre otras, la crisis del parlamentarismo, de la democracia o el egoísmo materialista. De modo más específico, respecto a España, acentúa el ambiente de tensión social en Barcelona. Sin ánimo exhaustivo, véanse, además de algunos ya citados, Morodo, R y González, J.C., "La Dictadura del general Primo de Rivera. Bibliografía general" en Boletín Informativo de Ciencias Politicas VIII-IX, 13-14 (1973), pp. 267-291; Cassasas Ymbert, J., La dictadura de Primo de Rivera (1923-1930). Textos, op. cit., pp. 9 y ss.; González Calbet, $\mathrm{M}^{\mathrm{a}}$ T., La dictadura de Primo de Rivera. El Directorio Militar, Madrid, 1987, pp. 19 y ss.; Gómez Navarro, J.L., El régimen de Primo de Rivera: Reyes, dictaduras y dictadores, Madrid, 1991, pp. 13 y ss.; Ben Ami, S., El cirujano de hierro. La dictadura de Primo de Rivera (1923-1930), Barcelona, 2012, pp. 17 y ss.

18 González Calbet, $\mathrm{M}^{\mathrm{a}}$ T., La dictadura de Primo de Rivera. El Directorio Militar, op. cit., p. 204: "La situación del orden público se encontraba entre las causas más inmediatas que habian 
vista las palabras de Ballbé19 cuando afirma que "el sistema de instituciones de orden público durante la Restauración, como hemos pretendido demostrar, era en buena parte el causante de la extrapolación de los conflictos sociales y políticos que conllevaba una radicalización en los movimientos reivindicativos, $\mathrm{y}$ provocaba una crisis cíclica que hacía tambalear al régimen" 20.

Para un periodista contemporáneo 21 como Diaz Retg22, "Primo de Rivera, para el Rey, como para la mayor parte de los españoles, fue el Hombre que se estaba esperando". Y, por lo que hacía a su obra, ésta era la "redención por la que un día y otro veníamos clamando". Habían transcurrido nada más que tres meses de gobierno y ya destacaba como méritos los contraídos en "moralidad, buena administración y renovación nacional"23. Y también en el "orden y sosiego público"24.

potenciado el golpe de Estado. Es necesario reconocer que, si bien antes del 13 de septiembre éste era un problema que representaba una verdadera inquietud cotidiana, no sólo para políticos y gobernadores, sino para amplias capas de la población, una vez Primo de Rivera en el poder el restablecimiento del orden público constituyó un cierto éxito del Directorio casi desde los primeros momentos". Véase, también, González Martínez, C., "La Dictadura de Primo de Rivera: una propuesta de análisis”, op. cit. pp. 345 y ss.

19 Ballbé, M., Orden público y militarismo en la España constitucional (1812-1983), op. cit., pp. 303-304.

20 Insiste, en p. 305: "La crisis del sistema viene originada, por tanto, en parte por una defectuosa estructuración de las instituciones, específicamente las de orden público, ya desde el principio".

${ }^{21}$ Calificado, no obstante, como panegirista del régimen por Ben Ami, S., El cirujano de hierro. La dictadura de Primo de Rivera (1923-1930), op. cit., p. 117.

22 Díaz Retg, E., España bajo el Nuevo Régimen. Cinco años de gobierno Primo de Rivera. 1923septiembre-1928, Madrid, 1928, p. 101.

23 Ben Ami, S., El cirujano de hierro. La dictadura de Primo de Rivera (1923-1930), op. cit., p. 92: "Durante sus primeros meses de gobierno, se ocupó de 18.920 asuntos, de los cuales 7.814 fueron 'resueltos', 8.122 transmitidos a algún ministerio y 3.614 sometidos por un general. E1 diluvio de decretos iba acompañado habitualmente de largas 'notas oficiosas' en las cuales el dictador mostraba su bonhomie, su ferviente patriotismo y una creencia casi mística en su 'intuición', esa palanca con la cual 'reconstruiria' y 'regeneraría' un 'Estado español decadente”.

24 Díaz Retg, E., España bajo el Nuevo Régimen. Cinco años de gobierno Primo de Rivera. 1923septiembre-1928, op. cit., p. 107: "Los hechos, que dicen más que las palabras, venían a demostrar en el curso de los tres primeros meses de la situación militar, y sucesivamente hasta el momento actual, que la obra del nuevo régimen, además de serlo de orden y sosiego público, lo era de también de moralidad, de buena administración y de renovación nacional...". Este autor, con anterioridad, habia destacado, el grave problema que representaba el sindicalismo revolucionario que, entre otras cosas, había traído "miedo ciudadano, el terror de los jurados y la dejadez de la autoridad". En ese sentido, Primo de Rivera, M., La obra de la dictadura. Sus últimos cuatro artículos, Madrid, 1930, en pp.8-9, al hilo de sus recuerdos, señala que, cuando en 1920 toma posesión de la Capitanía General de Valencia, conoció “.... el caso de que al alcalde de un pequeño pueblo próximo a la capital, Catarroja, lo habían asesinado a traición, al tomar el tranvía, unos sindicalistas de matiz comunista revolucionario, porque el muerto llevaba fama de autoridad firme en la persecución de los que, a título de tales, ejercían constante coacción en todas las organizaciones de trabajo. Dos semanas después, en el cruce de la carretera y vía férrea del Grao, eran acometidos a tiros por otro grupo de igual procedencia, el conde de Salvatierra, que había sido en Barcelona un excelente gobernador civil, su hermana y su esposa, que juntos paseaban en un coche de caballos, muriendo los dos primeros y siendo gravemente herida la última. Me ausenté unos dias, y durante ellos, el propio gobernador civil fué objeto de un atentado, a la salida del teatro, disparando sobre su coche una docena de tiros de revólver. Me reintegré en seguida a mi puesto, y hube de recoger en toda la ciudad un ambiente de pesimismo y 
Otro contemporáneo como Villanueva ${ }^{25}$ igualmente subraya que, al poco tiempo de subir al poder Primo de Rivera, "las calles de las grandes ciudades se vieron libres de los crimenes que las ensangrentaron durante los años 22 y 23 de esta década histórica... No se vieron totalmente libres pero sí aliviadas en la trágica inquietud de aquellos angustiosos momentos. Los partidarios de la autocracia como sistema de gobernar a los pueblos, registraron pronto el hecho en el haber del Directorio: - Ha restablecido el orden público. Los pistoleros no hacen acto de presencia en ninguna parte".

Más recientemente, González Calbet ${ }^{26}$ enfatiza que, "efectivamente, al poco tiempo de tener Primo de Rivera el poder en sus manos, cambió la vida del país en lo referente al orden público. Es en este sentido en el que se puede hablar de éxito del dictador"27. En esa politica de restablecimiento del orden público tuvo

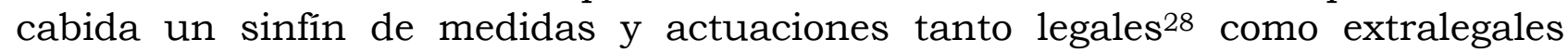
(ampliación de la jurisdicción militar, persecución de grupos políticos que propugnaban la violencia, pistolerismo paraestatal, endurecimiento de las

desmoralización, que me avergonzó, como autoridad, pues en el Círculo que más frecuentaba, en el Casino de la Agricultura, en el que tenía mi tertulia, durante la noche, se tomaban precauciones, desgraciadamente justificadas, pero que daban la sensación de un amedrentamiento incompatible con mi prestigio de primera autoridad militar, tanto más, cuanto contra el Gobierno el reproche era duro y constante, y yo lo representaba alli, pues el cargo de gobernador civil estuvo vacante una buena temporada, lo que fué fortuna, porque, puestos de acuerdo el secretario del Gobierno civil, el coronel de la Guardia civil y yo, tomamos algunas medidas que fueron para Valencia como de mano de santo, pues con ellas acabaron los atentados terroristas". En ese sentido, Fernández de la Reguera, R.; March, S., La Dictadura, I. El directorio militar: 1923-1925, Barcelona, 1969, pp. 185-186, resume los dos prioritarios objetivos del dictador: "Primo de Rivera, ya lo han leído ustedes, lo promete todo, lo resolverá todo: es la panacea universal... Esta dictadura, como cualquiera otra de su tipo, tendrá dos preocupaciones fundamentales: mimar al Ejército, porque es su salvaguardia, y atender a la clase obrera, porque ahí está el peligro. Habrá por lo tanto, orden...”.

25 Villanueva, F., La dictadura militar. II Tomo de 'Obstáculos tradicionales (crónica documentada de la oposición y de la represión bajo el Directorio), Madrid, 1930, p. 162.

26 González Calbet, M ${ }^{\mathrm{a}}$ T., La dictadura de Primo de Rivera. El Directorio Militar, op. cit., pp. 212213.

27 Aunque añadiendo al respecto: “... haciendo abstracción, forzosamente, de los medios que empleó para ello. El fin estaba conseguido...". Cassasas Ymbert, J., La dictadura de Primo de Rivera (1923-1930). Textos, op. cit., p. 34: "Digamos que el balance oficial de la obra del Directorio Militar al término de los primeros 90 dias, se decía que era general el reconocimiento de una mayor seguridad...". Tamames, R., Ni Mussolini ni Franco: la dictadura de Primo de Rivera y su tiempo, op. cit., p. 194: "La primera, el régimen del directorio militar... restableció la paz social, se aseguró el orden público y se puso en funcionamiento un sistema más ágil de administración central, provincial y municipal". Gózalez-Ruano, C., Quién fue.. El General Primo de Rivera, op. cit., p. 71: "El Directorio Militar, con una conciencia absoluta de su misión y con más aciertos que errores...".

28 Recuérdese que regía el Código Penal de 1870 que será sustituido en 1928 por otro nuevo más acorde a los planteamientos del nuevo régimen político. Pero también hay que tener en cuenta la vigencia de leyes penales especiales que regian en paralelo a aquél. Así, por ejemplo, el R.D. de 18 de septiembre de 1923 (Gaceta de 19 de septiembre de 1923) con medidas y sanciones contra el separatismo o el R.D. de 13 de abril de 1924 (Gaceta del 14 de abril de 1924) en virtud del cual "todos los delitos de robo a mano armada realizados contra establecimientos de comercio o banca, o sus oficinas o contra los Agentes contratistas o personas encargadas de valores" pasan a ser considerados delitos militares y juzgados en juicio sumarísimo, llegando a preceptuarse que, en caso de que, como consecuencia del robo, se produjeran lesiones o muerte, la pena debía oscilar entre la reclusión perpetua y la muerte. 
sanciones...) $)^{29}$. E instituciones legales pero que excepcionaban la propia legalidad, como el indulto, jugaron también un papel trascendente en este contexto.

Herrero Bernabé30 resume en cuatro las finalidades o "funciones" por las que, habitualmente, se conceden los indultos. Se otorgan por interés de la política general, por razones de política criminal, como beneficio penitenciario o como correctivo de la función juzgadora. Al hilo de la primera, el interés de la política general, alude este autor, por ejemplo, a "cuando un determinado tipo penal pierde valor social $\mathrm{y}$, en vez de suprimirlo, se utiliza el indulto para demagógicamente inaplicarlo". Así, tenemos casos relativamente recientes como el problema de los "insumisos" en nuestro país que al 'perdonarlos', al fin y cabo, no es más que una manera de atraerse simpatías populares recurriendo a la magnanimidad de quien detenta el poder. La amnistía, otra rama del derecho de gracia, ese olvidar y continuar, ese reseteo del curriculum penal de los condenados por causas fundamentalmente políticas, también hay que insertarla en este escenario de razones de conveniencia estratégica y de ese atraerse devociones multitudinarias. Obviamente, Primo de Rivera no podía dejar pasar la ocasión.

Melquíades Álvarez, en el prólogo que realiza para una obra titulada $L a$ dictadura y los procesos militares ${ }^{31}$, hace una distinción entre el significado de dictadura y cesarismo. Para él, el cesarismo "en el orden político es todavía algo peor, pues es casi siempre una degeneración morbosa de aquélla y la consecuencia inevitable de su prolongación injustificada en el Gobierno". En ese sentido, insiste en señalar que "las dictaduras, como tales dictaduras, tienen su disculpa y aún su justificación en la Historia. Surgen, desde luego, como un remedio heroico para prevenir un grave peligro social, y en tal sentido asumen momentáneamente la omnipotencia del Poder; pero siempre a condición de que desaparezcan tan pronto resulte el peligro conjurado. Así nacieron en Roma, que es el pueblo que nos ha legado, con el tesoro inapreciable de sus leyes, el modelo de dichas instituciones políticas, y así, legitimada por la necesidad, se da también el caso de que se registren en sus anales dictaduras excelsas, como la famosa de Cincinato, la cual, aún después de transcurridos muchos siglos, se recuerdan todavía con cierta veneración. Es, pues, atributo esencial de la Dictadura el que su vida en el Gobierno sea efimera y transitoria. Cuando se prolonga más de lo

29 González Calbet, M ${ }^{\mathrm{a}}$ T., La dictadura de Primo de Rivera. El Directorio Militar, op. cit., pp. 205206: "Su éxito inicial en el mantenimiento del orden público hay que buscarlo fundamentalmente en la 'virtualidad de un régimen de fuerza' que hizo desistir a los que antes intentaban perturbarlo. Se implantó el estado de guerra que duró casi dos años (hasta el 17 de mayo de 1925). En estos dos años todos los ciudadanos hubieron de soportar las dificultades de una vida civil con sus atribuciones claramente mermadas. Prohibición y regulación de reuniones, manifestaciones, prohibición incluso de 'corrillos en las calles', como decía el bando del capitán general de Cataluña, censura telefónica, telegráfica y sobre todo de prensa, etc.”. Para Ballbé, M., Orden público y militarismo en la España constitucional (1812-1983), op. cit., p. 306: "El régimen autoritario militar de Primo de Rivera no supone un cambio institucional en lo concerniente al orden público. Hay una continuidad en las técnicas jurídicas y aparatos de represión; aunque evidentemente ahora ésta alcanzará cotas muy superiores a las del régimen precedente". Véase también González Martínez, C., "La Dictadura de Primo de Rivera: una propuesta de análisis”, op. cit., pp. 348 y ss.

30 Herrero Bernabé, I., El Derecho de gracia: indultos, op. cit, pp. 133 y ss.

31 Blanco, C., La dictadura y los procesos militares, $1^{\text {a }}$ ed., Madrid, 1931, pp. XIV-XV. 
debido, la Dictadura sufre entonces una metamorfosis y el dictador se convierte inevitablemente en tirano. He aquí el origen del cesarismo".

Comienza pues el año 1924 y todo hace indicar que Primo de Rivera había decidido transitar de la dictadura al cesarismo. Su personal solución puntual pretende consolidarse y extenderse en el tiempo. Ha pasado más medio año desde el golpe de Estado y, sintiéndose vigoroso al frente del Directorio militar, trata de profundizar en medidas de que le garanticen la atracción de las masas a su causa $^{32}$. En este escenario se pueden inscribir normas como el R.D. de 12 de abril de 1924 (publicado en la Gaceta al dia siguiente) relativo a la concesión de indultos a los prófugos ${ }^{33}$ o el R.D. de 4 de julio de 1924 (publicado también al día siguiente), que va a conceder una amplia amnistía y una serie de indultos generales por la comisión de un amplio ramillete de delitos. Mientras que el primero se justifica porque hay compatriotas que, aunque eludieron sus obligaciones militares huyendo del país, están deseando su regreso la patria y "a

32 Ben Ami, S., El cirujano de hierro. La dictadura de Primo de Rivera (1923-1930), op. cit., p. 102: "Primo de Rivera se había vanagloriado, al comienzo, de que restauraria la independencia del poder judicial... Pero pronto quedó claro que en su esfuerzo por 'regenerar' la nación, el 'cirujano de hierro' no debia verse molestado por consideraciones legales o legalistas. Probablemente fue en las medidas paternalistas y arbitrarias aplicadas al sistema judicial que la dictadura más se pareció a una autocracia al viejo estilo".

33 "Artículo 1. Concedo indulto de los correctivos que les hubieren sido impuestos o que pudieran corresponderles, a los prófugos y a sus cómplices. Artículo 2. Los prófugos acogidos a esta gracia serán destinados a Cuerpo, y deberán servir en activo el tiempo que les corresponda para completar el que estuvieron o estén los demás individuos de su reemplazo y cupo. Artículo 3. Los mozos no alistados que se acojan a estos beneficios. serán incluidos en el primer alistamiento que se forme, teniendo los mismos derechos y obligaciones que los demás mozos inscritos en el mismo. Artículo 4. Los mozos no alistados y los demás prófugos podrán acogerse a los beneficios de la redención o de la cuota militar, según que pertenezcan a reemplazos anteriores o posteriores a la vigente ley de Reclutamiento, en los plazos de seis meses si estuvieran en Europa o en el de ocho si se hallaren fuera de ella; debiendo solicitar el indulto dentro de dichos plazos de las Autoridades militares españolas o en los Consulados de España en el extranjero. Artículo 5. Los que residan en el extranjero, pertenezcan a reemplazos posteriores a 1912 y deseen acogerse a los beneficios de la reducción del tiempo de servicio en filas que concede el capítulo 20 de la vigente ley de Reclutamiento, podrán satisfacer las cuotas mediante letras de cambio o resguardos del Banco de España, expedidos a favor de los Jefes de las Zonas de Reclutamiento, y al propio tiempo manifestarán el Cuerpo en que desean servir los cinco o diez meses que respectivamente les correspondan, incorporándose a filas para cumplir el primer período o el total del tiempo, si así les conviniese, en el plazo de dos años, a partir de la publicación de este Decreto, quedando dispensados de la presentación del certificado que acredite poseen la instrucción militar. Artículo 6. Los prófugos y mozos no alistados que sean de reemplazos anteriores a 1912, al acogerse a este indulto, podrán solicitar también la redención a metálico en la forma o condiciones, y con los requisitos que establecía la ley, verificando los pagos, los que residan en el extranjero, en la misma forma que se indica en el artículo anterior. Artículo 7. A los prófugos que residan en el extranjero se les notificará la concesión del indulto por conducto del Cónsul que cursó la instancia, y si no se presentan en la Zona correspondiente o en el Cuerpo de su destino dentro de los plazos señalados, a contar desde la notificación, quedará sin efecto la gracia concedida. Los de reemplazos anteriores al de 1912, que se rediman a metálico y residan en el extranjero, no necesitarán de esa presentación, remitiéndoseles el pase correspondiente por conducto de los Cónsules. Artículo 8. Quedará sin aplicación el indulto concedido por este Decreto si reincidieran en la misma falta o cometieran el delito o falta de deserción. Artículo 9. Por los Ministerios de Estado, Guerra y Gobernación se dictarán en la parte que a cada uno de ellos concierne las disposiciones necesarias para la ejecución del presente Decreto. Dado en Palacio a doce de Abril mil novecientos veinticuatro". 
los brazos de sus seres queridos que les aguardan"34, la segunda, también en un contexto bélico, se ampara en que las responsabilidades derivadas del desastre de Annual están a punto de materializarse, así como que la guerra de Marruecos está correctamente encauzada y pronto se esperan obtener generosos frutos:

"Muy diversas circunstancias aconsejan al Directorio la propuesta que a V. M. eleva de una amplia amnistía, y no es la menos señalada el fin a que tras larga y laboriosa tramitación se ha llegado en el proceso sustanciado contra el Alto Mando en Marruecos con motivo de los trágicos sucesos de Julio de $1921^{35}$.

....

En estas circunstancias, y cuando toda España da pruebas de quererse regenerar y ofrece sus voluntades y energias a una obra de resurgimiento; cuando el Poder público fortalecido no precisa de extremos rigores para mantener su prestigio y eficacia; cuando el Gobierno alienta la esperanza de reducir en breve el problema de Marruecos a términos en que sin intranquilidad, zozobra ni peligro de ruina se desenvuelva con normalidad en lo futuro esta acción de personalidad nacional fuera de fronteras, cree el Directorio prudente y acertado proponer a V, M. amplisimo indulto aplicable, no sólo a los sentenciados o procesados por causas originadas en el desastre de 1924, sino a otros que están encomendados a la justicia por delitos

34 "Millares de españoles residentes en varias Repúblicas de América elevan a V. M. una súplica de indulto del castigo que la ley impone a los prófugos, que les permita regresar a la Patria que añoran y a los brazos de sus seres queridos que les aguardan. Como las exigencias de la justicia no impiden el perdón en casos como el presente, parece natural abrir las puertas del solar patrio a los que sienten el ansia de volver a él. Pero el recuerdo de las amarguras por que atravesó la Nación, mientras algunos de sus hijos, sin preocuparse de ella, atendian a su propio bien, con olvido de sus deberes para la Patria, y la memoria de la sangre derramada y de las vidas perdidas por otros hermanos suyos, que las ofrendaron generosamente cuando España las necesitó, algunos de ellos sustituyendo a los ausentes, han de poner freno a la misericordia, toda vez que el perdón sin condiciones sería la desmoralizadora aprobación del acto punible, y el estímulo para que en el porvenir fuera repetido por cuantos sintieran con más fuerza los dictados de su egoísmo que los del deber hacia su Patria y sus conciudadanos. Por todo lo expuesto. Señor, y teniendo en cuenta que el indulto de la pena no puede eximir del cumplimiento del deber, tengo el honor de elevar a V. M., de acuerdo con el Directorio que presido, el siguiente proyecto de Decreto...”.

35 Continúa del siguiente modo: "La adversidad, que alguna vez se presenta a los mejores Ejércitos en forma de inesperada alarma, engendradora del pánico, que es expresión de todas las miserias y debilidades contrarias al honor militar, a que sólo los héroes escapan, quiso castigar al nuestro en esa infausta fecha valiéndose acaso del momentáneo desequilibrio mental o espiritual de un caudillo que en su brillante historia ofrecía hasta entonces garantía para encomendarle los más difíciles cometidos y someterlo a las más duras pruebas.

Posteriormente, por espacio de tres años, viene realizando el Ejército de África. en cooperación con la Marina de Guerra, labor que le ha hecho recobrar todo su prestigio y buen nombre y recuperar el amor y la confianza del país.

Graves fueron las horas de inolvidable amargura que entonces pasó España, y aún visten luto millares de familias por los hechos que hoy son objeto de resolución del más Alto Tribunal Militar; pero también la política las envenenó con sus pasiones, y de aquellos hechos y sus orígenes, en que pocos de los que los intervinimos dejamos de poner las manos pecadoras, se quiso hacer programa o plataforma desde las que se agitaron sentimientos que, por contrarios a la hidalguía española, no encontraron en el alma popular el eco ni el arraigo que esperaban sus promotores, restableciéndose pronto en la raza la serenidad característica de las que, por haber acometido las más extraordinarias empresas, no han podido librarse de unir a sus gloriosos triunfos los más acerbos dolores...". 
politicos o de prensa y aun comunes, seguro el Directorio de que este nuevo acto de clemencia de V.M. y su disposición a ser inexorable con los que entorpezcan la salvación del país con faltas o delitos, determinarán en todos un propósito de enmienda y bien obrar".

Cabe resaltar, aunque sea de forma muy breve respecto a la amnistía, que se concede a los supuestos en que haya habido condena (cualquiera que fuese la pena impuesta) por ${ }^{36}$ :

36 "REAL DECRETO. A propuesta del Jefe del Gobierno, Presidente del Directorio Militar, y de acuerdo con éste, Vengo en decretar lo siguiente: Artículo $1^{\circ}$ Concedo amnistía, cualquiera que sea la pena impuesta: A) A los condenados por delito o falta cometidos por medio de la imprenta, el grabado u otro medio mecánico de publicación, o por medio de la palabra hablada en reuniones, manifestaciones, espectáculos públicos o actos análogos de cualquier clase, exceptuándose los delitos de injuria y calumnia contra particulares y los que afectan a la integridad de la Patria. Asímismo se exceptúan todos los delitos a que se refieren las leyes de Propiedad literaria o industrial, 1a falsificaciones y los demás delitos de esta índole en cuanto comprenda intereses de tercero. Cuando se trate de delitos perseguibles sólo a instancia de parte y cometidos por medio de la Prensa u otro procedimiento mecánico de publicación, por Senadores y Diputados, si son hechos que se realizaron antes del 7 de Enero último, en que se suprimió la inmunidad parlamentaria, quedará en suspenso su tramitación judicial, cualquiera que sea el estado en que se encuentren, hasta que unas Cortes resuelvan sobre la concesión de sup1icatorio. B) A los condenados por delitos comprendidos en la ley Electoral vigente. C) A los condenados por las transgresiones previstas y penadas en la Ley de 27 de Abril de 1909, sobre coligaciones, huelgas y paros o con ocasión de los mismos, siempre que no se trate de delitos comunes ni del de insulto de obra a fuerza armada. D) A los castigados por desobediencia, cuando ésta hubiere consistido en quebrantamiento del destierro impuesto gubernativamente, conforme a las facultades que otorga la ley de 23 de Abril de 1870. E) A los delitos de negligencia previstos y penados en el artículo 275 del Código de Justicia Militar. E) A los castigados por haber contraído matrimonio con infracción de las disposiciones que regulan la materia en el Ejército y en la Armada, y a los Sacerdotes y Jueces municipales que los autorizaron. Artículo $2^{\circ}$. Será circunstancia indispensable para la concesión do la amnistía que las personas que hayan de disfrutarla estén presentes a disposición de las Autoridades españolas, o que se presenten en el plazo de un mes, a partir de la publicación de este Decreto. Artículo $3^{\circ}$. Los condenados a pena de muerte y aquellos que a la publicación de este Decreto hubiesen cometido un delito que se castigue con aquella pena, obtendrán, cuando haya sentencia firme que la imponga, su conmutación por la inmediata inferior exceptuándose los delitos comunes de traición, parricidio, robo con homicidio y todos los delitos de carácter militar. Artículo $4^{\circ}$. Concedo indulto total: Primero. A los castigados con pena de prisión militar correccional, cualquiera que sea su extensión. Segundo. A los condenados a las penas de arresto y destierro y suspensión. Tercero. A los castigados por los delitos de deserción y a sus auxiliares, inductores o encubridores, excepto cuando la deserción se hubiese realizado perteneciendo los desertores a los Cuerpos de África. Se aplicarán, sin embargo, a éstos los beneficios concedidos en el número 1 de este artículo, por razón de la pena impuesta. La gracia de indulto se otorga a los desertores a condición de que los interesados cumplan todos sus deberes militares, debiendo quedar sin efecto caso de volver a desertar antes de haber transcurrido cinco años. Cuarto. A los que sufren gubernativamente arresto en sustitución de multa y a todos los condenados por faltas, a penas leves, con arreglo al Código penal. Quinto. A los castigados con correctivos militares por faltas graves o leves, quedando obligados los responsables de falta grave de deserción, al cumplimiento de la misma condición establecida respecto a los desertores indultados en concepto de delito, según el último párrafo del apartado tercero de este artículo. Artículo $5^{\circ}$. Concedo indulto de la cuarta parte de la pena impuesta a los sentenciados a reclusión, relegación o extrañamiento temporales, y a presidio y prisión mayores y de la mitad a los sentenciados a presidio o prisión correccional, confinamiento e inhabilitación absoluta y especial temporales. También concedo rebaja de la sexta parte a todos aquellos a quienes no alcanzaren los beneficios anteriores por razón de la pena. Artículo $6^{\circ}$. Concedo indulto de la mitad de la pena impuesta a todos los que sufren penas militares por delitos esencialmente militares salvo lo dispuesto en el artículo $4^{\circ}$ y los que son objeto de 
- delitos o faltas cometidos bien por medio de la imprenta, el grabado u otro medio mecánico de publicación o bien por medio de la palabra hablada en reuniones, manifestaciones, espectáculos públicos o actos análogos de cualquier clase (con diversas excepciones);

- delitos comprendidos en la ley Electoral;

- transgresiones previstas y penadas en la Ley de 27 de abril de 1909 sobre coligaciones, huelgas y paros o con ocasión de los mismos (con matices);

- desobediencia (cuando ésta hubiere consistido en quebrantamiento del destierro impuesto gubernativamente)

- negligencia (contemplada en el artículo 275 del Código de Justicia Militar);

- haber contraído matrimonio con infracción de las disposiciones que regulan la materia en el Ejército y en la Armada (y a los sacerdotes y jueces municipales que los autorizaron).

Respecto a los ya condenados a pena de muerte (o pendientes de condena porque a la publicación del Decreto hubiesen cometido un delito castigado con dicha pena pero aún no hubiesen sido juzgados) se les conmuta a la inmediata inferior (exceptuándose los delitos de traición, parricidio, robo con homicidio y todos los delitos de carácter militar).

En cuanto a los indultos totales se concede a los condenados:

- con pena de prisión militar correccional;

- con penas de arresto y destierro y suspensión;

- por delitos de deserción y a sus auxiliares, inductores o encubridores (con varias condiciones y excepciones);

- a arresto gubernativo (en sustitución de multa);

- a penas leves por faltas;

amnistía. Artículo $7^{\circ}$. No se comprenden en la gracia de indulto las accesorias militares de pérdida de empleo y separación del servicio. Tampoco alcanzan los beneficios de la amnistía ni del indulto a los separados de Cuerpos u organismos del Estado por Tribunales de honor o sanciones gubernativas o administrativas. Artículo $8^{\circ}$. Quedan exceptuados de la gracia de indulto, cualquiera que sea el Código en que estén previstos los delitos de traición, espionaje, prevaricación, cohecho, parricidio, asesinato, robo con violencia en las personas, malversación de caudales comprendidos en los artículos 405 y 406 del Código penal, quebrantamiento de consigna por parte de los militares destinados a perseguir la defraudación de las Rentas públicas y los delitos que se persiguen únicamente a virtud de acción privada. A los castigados por los delitos que se persiguen de oficio consignados en el párrafo anterior, les concedo rebaja de la sexta parte de la pena si la sufriesen aflictiva y de la tercera si la sufriesen correccional. Artículo $9^{\circ}$. Son circunstancias indispensables para la concesión del indulto, que los reos estén cumpliendo condena o a disposición del Tribunal sentenciador y que hayan observado buena conducta desde que comenzaron a extinguir la pena, o desde la sentencia. Artículo 10. El Ministerio fiscal desistirá de las acciones penales entabladas o que deban entablarse por la responsabilidad de los delitos comprendidos en este Decreto, a los cuales se aplica la amnistía o el indulto total. E1 sobreseimiento libre se decretará por el Tribunal que corresponda, cualquiera que sea el estado del procedimiento. Artículo $11^{\circ}$. Serán indultados todos aquellos a quienes las Autoridades civiles y militares, en el ejercicio de sus atribuciones extraordinarias, hubiesen obligado a cambiar de domicilio y residencia. Dichos interesados podrán, desde la publicación de esto Decreto, residir donde lo tengan por conveniente. Artículo $12^{\circ}$. Por los Ministerios de Gracia y Justicia, Guerra y Marina, se dictarán las disposiciones necesarias para llevar a cumplimiento este Decreto, y por el de la Gobernación se darán las instrucciones precisas en lo que se refiere a la aplicación del artículo 11. Dado en Palacio a cuatro de Julio de mil novecientos veinticuatro". 
- con correctivos militares por faltas (con condiciones).

También se contemplan indultos de parte de la pena en los siguientes supuestos:

- De la mitad: a todos los que sufren penas militares por delitos esencialmente militares (con excepciones) y a los sentenciados a presidio o prisión correccional, confinamiento e inhabilitación absoluta y especial temporales.

- De la cuarta parte: a los sentenciados a reclusión, relegación o extrañamiento temporales, y a presido y prisión mayor.

- De la sexta parte a todos aquellos a quienes no alcanzaren los beneficios anteriores por razón de la pena.

\section{INDULTOS PARTICULARES}

Pero en este trabajo, más que en todas estas medidas genéricas, nos interesa centrarnos en los indultos particulares, en todos aquellos expedientes de los que nos da cuenta la Gaceta de Madrid durante el período del Directorio Militar. No hay que perder de vista que, como hemos aludido anteriormente además de razones de politica general, los indultos se pueden conceder bien por razones de politica criminal, como beneficio penitenciario o bien como correctivo de la función juzgadora ${ }^{37}$.

En este sentido, hemos contabilizado (salvo error u omisión) durante estos poco más de 26 meses un total de 158 Decretos (sin sumar los relativos a corrección de errores bien fuera por deslices en el nombre, en la pena, etc.). Se conceden por la magnanimidad de Alfonso XIII, siguiendo los preceptos de la ley de 18 de junio de 1870. En ese sentido, y de forma breve, cabe recordar que la ley permitía solicitar el indulto a los penados, a sus parientes o a cualquier otra persona en su nombre y, también, al tribunal sentenciador, el Supremo o el Fiscal de cualquiera de ellos. Del mismo modo, el Gobierno también estaba facultado para abrir el correspondiente expediente que diera inicio al proceso. El Ministerio de Gracia y Justicia era el destinatario de la documentación. Presentada la solicitud se iniciaba el consiguiente procedimiento que incluía el requerimiento tanto de un informe del tribunal sentenciador como el parecer del Consejo de Estado. Una vez conclusos estos pasos, un Decreto "motivado y acordado" en Consejo de Ministros y firmado por el monarca, establecía el indulto y sus posibles condiciones ${ }^{38}$.

No todos los decretos examinados aparecen redactados de la misma manera. Puede afirmarse, en cambio, la existencia de una especie de prototipo de carácter genérico coincidente en la inmensa mayoría de los casos que suele comenzar aludiendo de la toma de conocimiento del expediente ("Visto el expediente instruido) para enseguida dar cuenta de quién lo solicita (“... con motivo de la exposición elevada por...) y lo que pide ("que la pena de ... impuesta a ..., en causa por delito de ... sea conmutada por la de ..."). A continuación, se suele aludir a las circunstancias del caso en cuestión, la normativa vigente y el procedimiento seguido ("Considerando que... Vista la ley de 18 de junio de 1870,

37 Herrero Bernabé, I., El Derecho de gracia: indultos, op. cit, pp. 133 y ss.

38 Arts. 19 y ss. de la Ley de 18 de junio de 1870. 
que reguló el ejercicio de la gracia de indulto; en armonía con la Sala sentenciadora y con lo consultado por la Comisión permanente del Consejo de Estado, y conformándome con el parecer del Presidente del Directorio Militar, de acuerdo con éste) para, finalmente, determinar la decisión ("Vengo en conmutar por la de ... la pena impuesta a ..., en la causa y por el delito mencionados") y su rúbrica ("Dado en Palacio a ... ALFONSO. El Presidente del Directorio Militar Miguel Primo de Rivera y Orbaneja").

En coherencia con la parca, pero, sin embargo, muy interesante información ofrecida por el texto oficial hemos elaborado unas fichas que nos dan cuenta tanto del nombre del condenado, del delito o delitos cometidos, de la pena o penas impuestas, del indulto que se le concede, los motivos esgrimidos y el órgano o persona que lo solicita. De forma global podemos extraer datos como los siguientes. La variedad de delitos sobre los que recae el indulto es enorme. Hemos contabilizado más de una treintena. Los que más se indultan son los relacionados con los cometidos contra las personas tales como lesiones, homicidios (dolosos o por imprudencia), parricidios y asesinatos. Junto a éstos, aunque en menor número, también el hurto, el robo, los disparos, los atentados, las estafas, el desacato, las malversaciones de caudales públicos, las falsificaciones (tanto de documentos públicos y privados como de billetes de curso legal) y los abusos deshonestos. Con exigua frecuencia el contrabando, el alzamiento de bienes, la lesa majestad, el incendio, la violación, los insultos, las amenazas de muerte, las injurias graves, el cohecho, el alzamiento de bienes, la imprudencia temeraria, la negligencia, el allanamiento de morada, los daños, las multas, contra la salud pública, el orden público o los matrimonios ilegales. Hay otros en los que el carácter militar es muy marcado (bien sea por su propia naturaleza o por sus autores) tales como la excitación a la rebelión, la deserción, el abandono del puesto o el ejecutar actos con tendencia a ofender de obra a un superior. Finalmente, apuntar también que hay 3 supuestos en los que no se especifica el delito cometido ${ }^{39}$.

La inmensa mayoría de los indultos concedidos recae sobre los autores de delitos consumados, aunque hay un supuesto en el que se concede para un delito en grado de tentativa ${ }^{40}$, otro en grado de frustración ${ }^{41}$ y otro para un encubridor $^{42}$. También hay varios expedientes relacionados con delitos complejos, siendo el más habitual el robo con homicidio ${ }^{43}$ y el disparo con lesiones ${ }^{44}$. También el parricidio con homicidio o asesinato ${ }^{45}$. En menor medida, el hurto y desorden público ${ }^{46}$, el homicidio y disparo ${ }^{47}$, el desacato y daños ${ }^{48}$ y el allanamiento de morada y daños ${ }^{49}$.

\footnotetext{
39 Supuestos $n^{\circ} 65,86$ y 149.

40 Supuesto $\mathrm{n}^{\circ} 75$.

41 Supuesto $\mathrm{n}^{\circ} 131$.

42 Supuesto $n^{\circ} 154$.

43 Supuestos no 46, 71, 88, 89, 103 y 106.

44 Supuestos $n^{\circ} 8,31,63,66,85$ y 124.

45 Supuestos $n^{\circ} 10,42$ y 136.

46 Supuesto $n^{\circ} 5$.

47 Supuesto $\mathrm{n}^{\circ} 158$.
} 
El número de indultos a mujeres es relativamente bajo (probablemente unido al menor índice de delincuencia protagonizado por éstas). Concretamente 20 frente a los 156 otorgados a varones. Los delitos más frecuentes objeto de indulto en el caso de éstas son los hurtos (en 6 ocasiones), el parricidio (en 5 ocasiones en las cuales una se produce en concurso con un homicidio y en otra con un asesinato), las lesiones (2 supuestos), el homicidio, el robo, el disparo con lesiones (graves), las injurias (graves), la malversación, el desacato y la expedición de billetes falsos del Banco de España. Igualmente cabe destacar que hay algunos expedientes que no tienen un carácter individual, sino que afectan a más de una persona ${ }^{50}$. Del mismo modo, hay condenados que son indultados no por un delito sino por varios como los supuestos 25 (dos delitos de adquisición de billetes falsos), 47 (dos asesinatos), 49 (varios delitos de hurto), 52 (tres delitos de robo), 56 (tres de estafa), 57 (dos asesinatos), 62 (tres de hurto), 75 (dos de estafa), 137 (cuatro de homicidio y dos de lesiones), 138 (diecisiete delitos de estafa) y 154 (tres de hurto).

Buena parte de las solicitudes vienen de la mano del propio condenado o de su representante legal ${ }^{51}$. A veces, son los familiares más directos (como los padres, tíos, cónyuges, hijos o hermanos), los que toman la iniciativa ${ }^{52}$. También nos encontramos con algunos expedientes en los que son los vecinos, profesionales o autoridades locales los que avalan la solicitud ${ }^{53}$. Y cabe destacar también que no es menos importante el número de las solicitudes que vienen de la mano de la propia sala sentenciadora (Audiencias, Sala de Justicia del Consejo Supremo de Guerra y Marina, Tribunal Supremo), la fiscalía o alguna Séptima Región Militar). Incluso hay algunas en las que no se especifica el origen de la petición ${ }^{54}$.

En cuanto a la rebaja de pena casi siempre se hace caso a la petición elevada, aunque no como regla general (como en los supuestos $n^{\circ} 153^{55}$ o $157^{56}$ ). El indulto concedido, en ocasiones, es total (por ejemplo, los $n^{\circ} 129,130,148$ o 149) pero no siempre es así. Son muy numerosos los casos en los que simplemente hay una rebaja en cuanto al tiempo en un establecimiento penitenciario, pero sin que suponga la inmediata puesta en libertad del solicitante. No es infrecuente el canje de la privación de libertad por una multa

48 Supuesto $n^{\circ} 120$.

49 Supuesto $\mathrm{n}^{\circ} 133$.

50 Supuestos $\mathrm{n}^{\circ} 1,10,14,20,23,32,42,74,75,84,92,103,111,123$ y 138.

51 Supuestos $n^{\circ} 85,108,112$ y 158.

52 Supuestos $\mathrm{n}^{\circ}$ 28, 29, 36, 55, 57, 60, 101, 109, 110, 119, 122, 127, 137, 148, 149 y 156.

53 Supuestos $\mathrm{n}^{\circ} 51,81,99,135$ y 142 .

54 Supuestos $n^{\circ} 41$ a 48 y 65.

55 La Audiencia de Valladolid propone que los seis años y un día de prisión mayor se le conmuten por seis meses y un dia de prisión correccional. Sin embargo, se le indulta de todo lo que le queda por cumplir.

56 También, en este caso, es la Audiencia de Valladolid la que solicita que los catorce años, ocho meses y un día de reclusión temporal, impuestos al autor de un delito de homicidio sean conmutados por un año, diez meses y veintidós días de prisión correccional. Sin embargo, finalmente, sólo se concede un indulto parcial que le rebaja la pena a doce años y un día de reclusión temporal. 
(como en el $\mathrm{n}^{\circ}$ 17) o por destierro con idéntica duración de la condena o de lo que le falte por cumplir al penado57. En el caso de las penas de muerte se suelen cambiar por las de cadena perpetua ${ }^{58}$. Hay algún supuesto en el que la rebaja de pena es muy llamativa. Así, de reclusión perpetua a tan sólo seis años y un día de prisión mayor (supuesto $n^{\circ} 38$ ) o de pena de muerte al indulto total (supuesto $\mathrm{n}^{\circ}$ 49). También resultan llamativos los canjes que se producen en los supuestos 84, 147 y 154 que, respectivamente, establecen la permuta de tres años, seis meses y veintiún dias de presidio correccional por cuatro años de suspensión de cargo público y multa de 80 pesetas; en segundo lugar, la multa de 10.125 pesetas se cambia por un mes y un día de arresto mayor (en caso de insolvencia); $\mathrm{y}$, finalmente, hay un indulto del total del tiempo que queda por cumplir en la cárcel como consecuencia de la insolvencia para pagar una pena de multa cuya cuantía no se especifica.

Respecto a las motivaciones hay que señalar que son muy variadas ${ }^{59}$. Así:

- Unas fijan el foco de atención en las propias normas por:

○ sus posibles desajustes ${ }^{60}$;

- determinadas circunstancias han provocado su inaplicación ${ }^{61}$ :

- directamente se remite al uso de una prerrogativa constitucional ${ }^{62}$

- se recurre a una ley prevista para circunstancias especiales ${ }^{63}$.

- Otras se centran en la parte ofendida: así, la constancia de que ésta "no se opone al indulto", que "no se siente agraviada" o que no "sufrió perjuicio alguno"64.

57 Supuestos $\mathrm{n}^{\circ} 6,15,18,24,31,35,36,50,51,52,53,57,58,61,63,64,69,72,90,92,95$, $96,98,99,108,109,112,113,115,120,121,132,133,134,140,141,142,143$ у 151.

58 Supuestos $n^{\circ} 10,11,12,13,14,43,44,45,46,47,48,59,65$ (este caso es por reclusión militar perpetua), 71, 88, 89, 94, 103, 104, 105, 106, 107 у 136.

59 Estas argumentaciones se suelen utilizar por separado o conjuntamente según el supuesto concreto.

60 Esta es de las más frecuentes: "De la rigurosa aplicación de los preceptos legales resulta notoriamente excesiva la pena impuesta, con relación al daño causado y grado de malicia que revela".

61 Supuesto $\mathrm{n}^{\circ}$ 81: "que no le han alcanzado los beneficios de los Reales decretos de amnistía e indulto general de 1919 y 1924"; supuesto $\mathrm{n}^{\circ}$ 101: "Considerando las circunstancias que concurrieren en el hecho delictivo y las que han determinado que no le hayan podido ser aplicados los beneficios del indulto general de 4 de Julio último, así como el perdón de la parte ofendida".

62 Supuestos $n^{\circ} 65$ o 71 : “... la prerrogativa que me confiere el número $3^{\circ}$ del artículo 54 de la Constitución".

63 Supuesto $\mathrm{n}^{\circ}$ 86: "Visto lo dispuesto en el artículo $5^{\circ}$ de la ley de 28 de Diciembre de 1918 , dictada para la aplicación en el fuero de guerra, la de 23 de Julio de 1914 y de acuerdo con lo informado por el Consejo Supremo de Guerra y Marina...".

${ }^{64}$ Incluso a veces renunciando a la correspondiente indemnización. 
- También están las que recurren al autor del delito bien antes del mismo65, durante (porque existen dudas respecto de su autoría66, su posible participación ${ }^{67}$, su intencionalidad 68 o porque el estado en que se encontraba cuando lo cometió revelaba la merma de sus facultades ${ }^{69}$ ) o bien con posterioridad (hay "pruebas de arrepentimiento por parte del penado", "está probada su buena conducta", el "tiempo de cumplimiento de condena que lleva el penado"70, su edad71, el mal estado de salud al cumplir la condena $\left.{ }^{72} \ldots\right)$.

- Las que tienen en cuenta las circunstancias del hecho delictivo en sín "los antecedentes y circunstancias posteriores al mismo" así como la naturaleza del hecho ${ }^{74} \mathrm{y}$ el hecho de que no sea frecuente o no provoque alarma social ${ }^{75}$ o que sea de escasa gravedad ${ }^{76}$.

- Las relacionadas con la naturaleza de la pena77.

- Las que se atienden en función de la presión social ${ }^{78}$.

- Las que tienen un carácter eminentemente religioso ${ }^{79}$.

65 Supuestos $\mathrm{n}^{\circ} 124$ o 132: “Considerando... su falta de antecedentes penales". Supuesto $\mathrm{n}^{\circ}$ 142: "Considerando... sus servicios en el Ejército".

66 Supuesto no 49: “Considerando que según consta del referido expediente las actuaciones judiciales practicadas después de ejecutada la sentencia condenatoria dan fundamento racional para juzgar que se cometió en ellas error en persona. Considerando que desde el momento en que no hay certidumbre de que el penado sea el verdadero culpable, exige la justicia que no continúe sufriendo la condena...".

67 Supuesto $\mathrm{n}^{\circ} 23$.

68 Supuesto $n^{\circ}$ 25: "Que, al parecer, sólo tuvo intención de cometer un delito de tenencia de billetes falsos...".

69 Supuesto $n^{\circ}$ 51: “Considerando... el estado de embriaguez del penado al cometerlo...”.

70 Supuesto $n^{\circ}$ 137: “Considerando los muchos años de privación de libertad que lleva el penado...".

71 Supuesto $\mathrm{n}^{\circ}$ 140: "Considerando... la avanzada edad del penado...".

72 Supuesto $\mathrm{n}^{\circ}$ 92: “Considerando... especialmente con respecto a Luis Marcelo Gaspar, su mal estado de salud"; supuesto $\mathrm{n}^{\circ} 112$ : "Considerando... su quebrantada salud..."; supuesto $\mathrm{n}^{\circ}$ 120: "Considerando... y su quebrantada salud".

73 En algún caso se habla de las "circunstancias especiales" del caso (supuesto $n^{\circ} 87$ ), "especialísimas" (supuesto $n^{\circ} 95$ ) o "excepcionales" (supuesto $n^{\circ} 103$ ).

74 Supuesto $n^{\circ} 32$ : “Considerando la naturaleza del hecho delictivo, que más que malicia revela ignorancia..."; supuesto $n^{\circ}$ 130: “Considerando que en el presente caso concurren circunstancias de equidad y que se trata delito de carácter politico cometido por medio de la Prensa".

75 Supuesto $n^{\circ}$ 92: “Considerando la indole del delito, que no produjo alarma ni es frecuente en el territorio de aquella Audiencia...".

76 Supuesto $\mathrm{n}^{\circ}$ 126: “Considerando... la escasa gravedad del hecho de autos, ya que ejerció la profesión poco antes de concluir los estudios de su carrera”.

77 Supuesto n ${ }^{\circ}$ 147: “Considerando... que Gregorio Cerezo Cardaño, al parecer por insolvencia, no ha satisfecho la parte de multa que le corresponde, debiendo, por tanto, sufrir la sustitutoria personal equivalente"; supuesto $n^{\circ}$ 154: "Considerando... que la prisión que sufre se deriva de su insolvencia".

78 Supuesto no 99: “Considerando la unanimidad con que las Autoridades y convecinos del penado solicitan su indulto..."; supuesto $n^{\circ} 135$ : “Considerando que la parte agraviada se adhiere y firma la solicitud de indulto de los vecinos de Valencia...". 


\section{FICHAS}

$\mathrm{N}^{\mathrm{o}} 1$

Fecha de publicación: 14 de octubre de 1923

Órgano del que procede la petición: Audiencia de Salamanca

Delito cometido: Hurto

Pena impuesta: Dos años, cuatro meses y un día de presidio correccional

Conmutada por: Seis meses de arresto mayor

Beneficiarios: Rafael Martín Pescador y Doroteo Baladrón Jiménez

Motivo por el que se justifica: "De la rigurosa aplicación de los preceptos legales resulta notoriamente excesiva la pena impuesta, con relación al daño causado y grado de malicia que revela".

\section{$\mathrm{N}^{\circ} 2$}

Fecha de publicación: 14 de octubre de 1923

Órgano del que procede la petición: Audiencia de Badajoz

Delito cometido: Hurto doméstico

Pena impuesta: Cuatro años, dos meses y un día de prisión correccional

Conmutada por: Un año, un mes y once dias de igual prisión.

Beneficiaria: Isabel Bernal Dominguez

Motivo por el que se justifica: "De la rigurosa aplicación de los preceptos legales resulta notoriamente excesiva la pena impuesta, con relación al daño causado y grado de malicia que revela".

$\mathrm{N}^{\mathrm{o}} 3$

Fecha de publicación: 26 de octubre de 1923

Órgano del que procede la petición: Audiencia de Las Palmas

Delito cometido: Matrimonio ilegal

Pena impuesta: Ocho años y un día de prisión mayor

Conmutada por: Un año de prisión correccional y reprensión pública

Beneficiario: Juan Marrero Saavedra

Motivo por el que se justifica: "De la rigurosa aplicación de los preceptos legales resulta notoriamente excesiva la pena impuesta con relación al daño causado y grado de malicia que revela”.

\section{$\mathrm{N}^{\circ} 4$}

Fecha de publicación: 26 de octubre de 1923

Órgano del que procede la petición: Audiencia de Córdoba

Delito cometido: Abusos deshonestos

Pena impuesta: Cuatro años nueve meses y once días de prisión correccional

Conmutada por: Un año, ocho meses y un día de igual prisión

Beneficiario: Manuel Padillo Urbano

Motivo por el que se justifica: "De la rigurosa aplicación de los preceptos legales resulta notoriamente excesiva la pena impuesta con relación al daño causado y grado de malicia que revela".

79 Supuestos 41 al 48 y 104 al 107: Tradición religiosa del acto de la adoración de la Santa Cruz: "Teniendo en cuenta que los Reyes de España han solemnizado siempre el día de hoy, en que la Iglesia conmemora el misterio de la redención del género humano, con el indulto de algunos reos condenados a la última pena, piadosa costumbre que es muy grata a Mi Corazón continuar observando". 
$\mathrm{N}^{\circ} 5$

Fecha de publicación: 30 de octubre de 1923

Órgano del que procede la petición: Audiencia de Barcelona

Delito cometido: Complejo de hurto y desorden público

Pena impuesta: Un año, diez meses y veintidós días de prisión correccional

Conmutada por: Cinco meses y doce dias de arresto mayor

Beneficiario: Miguel Clapés Abancó

Motivo por el que se justifica: "De la rigurosa aplicación de los preceptos legales resulta notoriamente excesiva la pena impuesta con relación al daño causado y grado de malicia que revela".

$\mathrm{N}^{\circ} 6$

Fecha de publicación: 22 de diciembre de 1923

Órgano del que procede la petición: Sala de lo Criminal del Tribunal Supremo 80

Delito cometido: Lesiones graves

Pena impuesta: Un año y un día de prisión correccional

Conmutada por: Destierro a 25 kilómetros de San Sebastián

Beneficiario: Romualdo Rebollar González

Motivo por el que se justifica: "De la rigurosa aplicación de los preceptos legales resulta notoriamente excesiva la pena impuesta en relación al daño causado y el grado de malicia que revela".

$\mathrm{N}^{\circ} 7$

Fecha de publicación: 22 de diciembre de 1923

Órgano del que procede la petición: Audiencia de Toledo

Delito cometido: Atentado

Pena impuesta: Un año y un día de prisión correccional

Conmutada por: Seis meses y un dia de prisión correccional

Beneficiario: Casimiro Torrejón García

Motivo por el que se justifica: "De la rigurosa aplicación de los preceptos legales resulta notoriamente excesiva la pena impuesta en relación al daño causado y el grado de malicia que revela".

$\mathrm{N}^{\circ} 8$

Fecha de publicación: 22 de diciembre de 1923

Órgano del que procede la petición: Sala de lo Criminal del Tribunal Supremo

Delito cometido: Disparo y lesiones graves

Pena impuesta: Dos años y veinte dias de prisión correccional

Conmutada por: Cuatro meses y un día de arresto mayor

Beneficiario: Miguela Calvo Tejedor

Motivo por el que se justifica: "De la rigurosa aplicación de los preceptos legales resulta notoriamente excesiva la pena impuesta en relación al daño causado y el grado de malicia que revela".

$\mathrm{N}^{\circ} 9$

80 En los casos del Tribunal Supremo, a veces, no se especifica el verdadero promotor de la petición. Se deja constancia de que ha habido un recurso de casación desestimado y, en consecuencia, se eleva la petición de indulto. 
Fecha de publicación: 28 de diciembre de 1923

Órgano del que procede la petición: Audiencia de Zaragoza

Delito cometido: Parricidio

Pena impuesta: Cadena perpetua y accesorias

Conmutada por: Quince años de reclusión temporal y accesorias.

Beneficiario: Lorenzo Puyoles Borderas

Motivo por el que se justifica: "De la rigurosa aplicación de los preceptos legales resulta notoriamente excesiva la pena impuesta en relación al daño causado y el grado de malicia que revela".

$\mathrm{N}^{\mathrm{o}} 10$

Fecha de publicación: 23 de enero 1924

Órgano del que procede la petición: Audiencia de León (la Sala de lo Criminal del Tribunal Supremo niega el recurso de casación)

Delito cometido: Homicidio y parricidio

Pena impuesta: Pena de muerte

Conmutada por: Cadena perpetua y reclusión perpetua, respectivamente, con las accesorias correspondientes.

Beneficiarios: Melquiades Iglesias Lozano y Petra Pedroche Lozano

Motivo por el que se justifica: "Considerando las circunstancias que concurren en el caso se hace uso de la prerrogativa del número $3^{\circ}$ del artículo 54 de la Constitución vigente".

$\mathrm{N}^{\circ} 11$

Fecha de publicación: 23 de enero 1924

Órgano del que procede la petición: Audiencia de Guadalajara (la Sala de lo Criminal del Tribunal Supremo niega el recurso de casación)

Delito cometido: Parricidio

Pena impuesta: Pena de muerte

Conmutada por: Cadena perpetua con sus accesorias

Beneficiario: Faustino Marco Ortega

Motivo por el que se justifica: "Considerando las circunstancias que concurren en el caso se hace uso de la prerrogativa que concede el número $3^{\circ}$ del artículo 54 de la Constitución vigente".

$\mathrm{N}^{\mathrm{o}} 12$

Fecha de publicación: 23 de enero 1924

Órgano del que procede la petición: Audiencia de Ciudad Real (la Sala de lo Criminal del Tribunal Supremo niega el recurso de casación)

Delito cometido: Parricidio

Pena impuesta: Muerte

Conmutada por: Cadena perpetua con sus accesorias

Beneficiario: José San Juan Martínez

Motivo por el que se justifica: "Considerando las circunstancias que concurren en el caso se hace uso de la prerrogativa que concede el número $3^{\circ}$ del artículo 54 de la Constitución vigente".

$\mathrm{N}^{\mathrm{o}} 13$

Fecha de publicación: 23 de enero 1924 
Órgano del que procede la petición: Audiencia de Lérida (la Sala de lo Criminal del Tribunal Supremo niega el recurso de casación)

Delito cometido: Asesinato

Pena impuesta: Muerte

Conmutada por: Cadena perpetua con sus accesorias

Beneficiario: José Soro Pujol

Motivo por el que se justifica: "Considerando las circunstancias que concurren en el caso se hace uso de la prerrogativa que concede el número $3^{\circ}$ del artículo 54 de la Constitución vigente".

$\mathrm{N}^{\circ} 14$

Fecha de publicación: 23 de enero 1924

Órgano del que procede la petición: Audiencia de Madrid (la Sala de lo Criminal del Tribunal Supremo niega el recurso de casación)

Delito cometido: Asesinato

Pena impuesta: Muerte

Conmutada por: Cadena perpetua con sus accesorias

Beneficiarios: Pedro Mateu Cusidó y Luis Nicolau Fort

Motivo por el que se justifica: "Considerando las circunstancias que concurren en el caso se hace uso de la prerrogativa que concede el número $3^{\circ}$ del artículo 54 de la Constitución vigente".

$\mathrm{N}^{\mathrm{o}} 15$

Fecha de publicación: 9 de marzo de 1924

Órgano o persona de la que procede la petición: El propio interesado

Delito cometido: Disparo

Pena impuesta: Un año y un día de prisión correccional

Conmutada por: Destierro el resto de la pena que le falta por cumplir

Beneficiario: Daniel Serres Campos

Motivo por el que se justifica: "La parte ofendida no se opone al indulto, hay pruebas de arrepentimiento por parte del penado y está probada su buena conducta".

$\mathrm{N}^{\circ} 16$

Fecha de publicación: 9 de marzo de 1924

Órgano del que procede la petición: Audiencia de Barcelona

Delito cometido: Expedición de billetes falsos del Banco de España

Pena impuesta: Catorce años, ocho meses y un día de reclusión temporal

Conmutada por: Dos años, cuatro meses y un día de prisión correccional y multa de 250 pesetas.

Beneficiario: Angela Segui Condominas

Motivo por el que se justifica: "De la rigurosa aplicación de los preceptos legales resulta notoriamente excesiva la pena impuesta en relación al daño causado y el grado de malicia que revela".

$\mathrm{N}^{\mathrm{o}} 17$

Fecha de publicación: 9 de marzo de 1924

Órgano del que procede la petición: Audiencia de Ávila

Delito cometido: Cohecho

Pena impuesta: Un año, ocho meses y veintiún dias de presidio correccional 
Conmutada por: 125 pesetas de multa o el apremio personal subsidiario correspondiente

Beneficiario: Nicolás González García

Motivo por el que se justifica: "De la rigurosa aplicación de los preceptos legales resulta notoriamente excesiva la pena impuesta en relación al daño causado y el grado de malicia que revela".

$\mathrm{N}^{\mathrm{o}} 18$

Fecha de publicación: 9 de marzo de 1924

Órgano o persona de la que procede la petición: El propio interesado

Delito cometido: Atentado

Pena impuesta: Dos años, cuatro meses y un día de prisión correccional

Conmutada por: Destierro

Beneficiario: Manuel Díaz Aguilar

Motivo por el que se justifica: "Considerando las circunstancias que en el hecho concurrieron, que la parte ofendida no se opone al indulto y la buena conducta que viene observando el penado".

\section{$\mathrm{N}^{\circ} 19$}

Fecha de publicación: 9 de marzo de 1924

Órgano o persona de la que procede la petición: El propio interesado

Delito cometido: Asesinato

Pena impuesta: Cadena perpetua

Conmutada por: Dos años, cuatro meses y un día de prisión correccional (de la pena que le resta).

Beneficiario: Juan Bernardino García

Motivo por el que se justifica: El tiempo de cumplimiento de condena que lleva el penado y su buena conducta y arrepentimiento

$\mathrm{N}^{\circ} 20$

Fecha de publicación: 9 de marzo de 1924

Órgano del que procede la petición: Audiencia de Barcelona

Delito cometido: Falsificación de billetes del Banco de España

Pena impuesta: Catorce años, ocho meses y un día de cadena temporal

Conmutada por: Cuatro años de presidio correccional.

Beneficiarios: Adrián Ferreres Ferrando y Francisco Illá Marsal

Motivo por el que se justifica: "De la rigurosa aplicación de los preceptos legales resulta notoriamente excesiva la pena impuesta en relación al daño causado y el grado de malicia que revela".

$\mathrm{N}^{\mathrm{o}} 21$

Fecha de publicación: 9 de marzo de 1924

Órgano del que procede la petición: Audiencia de Murcia

Delito cometido: Parricidio

Pena impuesta: Cadena perpetua

Conmutada por: Doce años y un día de cadena temporal y accesorias

Beneficiario: José Robles Mario

Motivo por el que se justifica: "De la rigurosa aplicación de los preceptos legales resulta notoriamente excesiva la pena impuesta en relación al daño causado y el grado de malicia que revela”. 
$\mathrm{N}^{\mathrm{o}} 22$

Fecha de publicación: 11 de marzo de 1924

Órgano del que procede la petición: Audiencia de Zaragoza

Delito cometido: Atentado

Pena impuesta: Dos años, cuatro meses y un día de prisión correccional

Conmutada por: Cinco meses de arresto mayor

Beneficiario: Santiago Manuel Marín Gaspar

Motivo por el que se justifica: "De la rigurosa aplicación de los preceptos legales resulta notoriamente excesiva la pena impuesta en relación al daño causado y el grado de malicia que revela".

\section{$\mathrm{N}^{\mathrm{o}} 23$}

Fecha de publicación: 14 de marzo de 1924

Órgano o personas de las que procede la petición: Los propios interesados

Delito cometido: Asesinato

Pena impuesta: Cadena perpetua

Conmutada por: A Benigno Blázquez Pérez del resto de su pena y a Francisco Izquierdo Blázquez quince años de reclusión temporal

Beneficiarios: Benigno Blázquez Pérez y Francisco Izquierdo Blázquez

Motivo por el que se justifica: "Considerando las circunstancias que concurrieron en el delito, que establecen dudas respecto a la participación que en el mismo tomó Benigno Blázquez Pérez y que modificarían la calificación del delito para ambos penados; el tiempo que llevan de cumplimiento de condena, y su buena conducta y arrepentimiento".

\section{$\mathrm{N}^{\circ} 24$}

Fecha de publicación: 14 de marzo de 1924

Órgano o persona de la que procede la petición: La propia interesada

Delito cometido: Desacato

Pena impuesta: Un año y un día de prisión correccional

Conmutada por: Destierro

Beneficiario: Luisa María de Funes y Galarza

Motivo por el que se justifica: "Considerando las especiales circunstancias que concurren en el penado, su buena conducta y las muestras de arrepentimiento de que viene dando pruebas".

\section{$\mathrm{N}^{\mathrm{o}} 25$}

Fecha de publicación: 14 de marzo de 1924

Órgano o persona de la que procede la petición: El propio interesado

Delito cometido: Dos delitos de adquisición de billetes falsos

Pena impuesta: Dos penas de catorce años, ocho meses y un dia de reclusión temporal

Se le conmuta: El resto de las penas que le faltan por cumplir.

Beneficiario: Saturio Espinosa Moro

Motivo por el que se justifica: "Que, al parecer, sólo tuvo intención de cometer un delito de tenencia de billetes falsos; el tiempo que lleva de cumplimiento de condena, su buena conducta y pruebas de arrepentimiento y que su correo ha sido ya indultado". 
$\mathrm{N}^{\mathrm{o}} 26$

Fecha de publicación: 19 de marzo de 1924

Órgano o persona de la que procede la petición: La propia interesada

Delito cometido: Hurto

Pena impuesta: Arresto mayor la pena de dos años, cuatro meses y un día de prisión correccional

Conmutada por: Dos meses de arresto mayor el resto de la pena que le falta por cumplir.

Beneficiaria: Josefa Rodríguez Gil

Motivo por el que se justifica: "Considerando las circunstancias que en el hecho concurrieron, el perdón de la parte agraviada y la buena conducta anterior y posterior al delito de 1a penada".

$\mathrm{N}^{\mathrm{o}} 27$

Fecha de publicación: 19 de marzo de 1924

Órgano o persona de la que procede la petición: El propio interesado

Delito cometido: Matrimonio ilegal

Pena impuesta: Ocho años y un dia de prisión mayor.

Se le conmuta: El resto de la pena de a que fue condenado

Beneficiario: José María Llamazales García

Motivo por el que se justifica: "Considerando que la parte ofendida perdona y no se opone al indulto, el tiempo de cumplimiento de condena que lleva el penado y su buena conducta”.

$\mathrm{N}^{\mathrm{o}} 28$

Fecha de publicación: 19 de marzo de 1924

Órgano o persona de la que procede la petición: Ana Martín Berraquero (esposa del condenado)

Delito cometido: Disparo

Pena impuesta: Un año, ocho meses y veintiún días de prisión correccional

Se le conmuta: El resto de la pena que le falta por cumplir.

Beneficiario: Antonio Flores Berraquero

Motivo por el que se justifica: "Considerando que la parte agraviada no se opone al indulto y los antecedentes del hecho delictivo, circunstancias posteriores al mismo".

$\mathrm{N}^{\circ} 29$

Fecha de publicación: 19 de marzo de 1924

Órgano o persona de la que procede la petición: Consuelo Pantoja García (esposa del condenado)

Delito cometido: Contra la salud pública

Pena impuesta: Un año y un día de prisión correccional y 125 pesetas de multa

Se le conmuta: El resto de la pena que le queda por cumplir.

Beneficiario: Restituto Pajares Maroto

Motivo por el que se justifica: "Considerando el tiempo de cumplimiento de condena que lleva el penado y su buena conducta y arrepentimiento".

$\mathrm{N}^{\circ} 30$

Fecha de publicación: 26 de marzo de 1924

Órgano o persona de la que procede la petición: El propio interesado. 
Delito cometido: Incendio

Pena impuesta: Cadena perpetua

Conmutada por: Cadena temporal

Beneficiario: Gervasio Gómez de Miguel

Motivo por el que se justifica: "Considerando las circunstancias que concurrieron en el hecho delictivo, la buena conducta del penado y el tiempo que lleva de cumplimiento de condena".

\section{$\mathrm{N}^{\mathrm{o}} 31$}

Fecha de publicación: 26 de marzo de 1924

Órgano o persona de la que procede la petición: El propio interesado

Delito cometido: Disparo y lesiones.

Pena impuesta: Tres años, nueve meses y cinco dias de presidio correccional

Conmutada por: Destierro el resto de la pena que le falta por cumplir

Beneficiario: Miguel Campaña Gaitica

Motivo por el que se justifica: "Considerando la buena conducta que el penado viene observando, el tiempo que lleva de cumplimiento de condena y que la parte ofendida no se opone al indulto".

$\mathrm{N}^{\circ} 32$

Fecha de publicación: 26 de marzo de 1924

Órgano o personas de las que procede la petición: Los propios interesados

Delito cometido: Hurto

Pena impuesta: Un año, ocho meses y veintiún días de presidio correccional

Se le conmuta: El resto de la pena que les falta por cumplir

Beneficiarios: Manuel Pérez Páez y Leonardo Gregorio Prados Jiménez

Motivo por el que se justifica: "Considerando la naturaleza del hecho delictivo, que más que malicia revela ignorancia, el no haberle seguido perjuicio alguno al agraviado y la buena conducta y arrepentimiento de los penados".

\section{$\mathrm{N}^{\mathrm{o}} 33$}

Fecha de publicación: 1 de abril de 1924

Órgano o persona de la que procede la petición: El propio interesado

Delito cometido: Amenazas de muerte

Pena impuesta: Doce años, cuatro meses y un día de prisión correccional

Se le conmuta: El resto de la pena que le falta por cumplir

Beneficiario: Manuel Martínez Orduña

Motivo por el que se justifica: "Considerando la naturaleza del delito, que la parte ofendida no se opone al indulto y el tiempo que lleva el penado de cumplimiento de la pena".

$\mathrm{N}^{\circ} 34$

Fecha de publicación: 1 de abril de 1924

Órgano o persona de la que procede la petición: La propia interesada

Delito cometido: Hurto

Pena impuesta: Un año, ocho meses y veintiún días de prisión correccional

Se le conmuta: El resto de la pena que le falta por cumplir

Beneficiario: Carolina Úrsula Araujo Sotelo

Motivo por el que se justifica: "Considerando la índole del delito, que e1 agraviado no sufrió perjuicio alguno y que éste no se opone al indulto". 
$\mathrm{N}^{\circ} 35$

Fecha de publicación: 1 de abril de 1924

Órgano o persona de la que procede la petición: El propio interesado

Delito cometido: Lesiones graves

Pena impuesta: Un año, ocho meses y veintiún dias de prisión correccional

Conmutada por: Destierro a 200 kilómetros del lugar donde delinquió, el resto de la pena que le falta por cumplir.

Beneficiario: Cesáreo Encinas García

Motivo por el que se justifica: "Considerando que la parte ofendida no se opone al indulto, las circunstancias que concurrieron en el hecho delictivo y la buena conducta y pruebas de arrepentimiento del penado".

$\mathrm{N}^{\circ} 36$

Fecha de publicación: 1 de abril de 1924

Órgano del que procede la petición: Maria Luisa De Vos (hermana del condenado). Delito cometido: Estafa ${ }^{81}$

Pena impuesta: Cuatro meses y un día de arresto mayor

Conmutada por: "Igual tiempo de destierro, el resto de la pena que le falte por cumplir..., después de que extinga tres meses de la de arresto mayor que le ha sido impuesta".

Beneficiario: Manuel Eusebio Florencio Bernardo De Vos Obregón

Motivo por el que se justifica: "Considerando la índole del delito, la buena conducta y muestras de arrepentimiento del penado".

$\mathrm{N}^{\circ} 37$

Fecha de publicación: 10 de abril de 1924

Órgano o persona de la que procede la petición: El propio interesado

Delito cometido: Disparo

Pena impuesta: Un año, ocho meses y veintiún dias de prisión correccional

Se le conmuta: El resto de la pena que le falta por cumplir

Beneficiario: Juan José López Avalos

Motivo por el que se justifica: "Considerando las circunstancias que concurrieron en el hecho delictivo, la buena conducta y pruebas de arrepentimiento del penado y que la parte agraviada otorga su perdón”.

81 Hubo un error a la hora de la publicación de la Gaceta en cuanto al delito cometido. En realidad el indultado había cometido una estafa aunque inicialmente se había publicado como autor de un hurto: Gazeta del 2 de abril de 1924: "Rectificación de error respecto del Decreto de Manuel Eusebio Florencio Bernando de Vos Obregón: Habiéndose padecido un error de copia en el Real Decreto de conmutación de la pena impuesta a Manuel Eusebio Florencio Bernardo De Vos Obregón., publicado en la Gaceta del día 1 del actual, se inserta a continuación debidamente rectificado. Visto el expediente instruido con motivo de instancia elevada por doña María Luisa De Vos, en súplica de que a su hermano Manuel Eusebio Florencio Bernardo De Vos Obregón le sea conmutada por destierro la pena de cuatro meses y un día de arresto mayor a que fue condenado por la Audiencia de Pamplona en causa por delito de estafa, Considerando la índole del delito y la buena conducta y muestras de arrepentimiento del penado... Vengo en conmutar, por igual tiempo de destierro, el resto de la pena que le falte por cumplir". 
$\mathrm{N}^{\mathrm{o}} 38$

Fecha de publicación: 10 de abril de 1924

Órgano del que procede la petición: Audiencia de Badajoz

Delito cometido: Parricidio

Pena impuesta: Reclusión perpetua

Conmutada por: Seis años y un día de prisión mayor

Beneficiario: Antonia Pascuaza Gil Carball

Motivo por el que se justifica: "Considerando que de la rigurosa aplicación de los preceptos legales resulta notoriamente excesiva la pena impuesta con relación al daño causado y grado de malicia que revela".

$\mathrm{N}^{\mathrm{o}} 39$

Fecha de publicación: 10 de abril de 1924

Órgano del que procede la petición: Audiencia de Zamora

Delito cometido: Robo

Pena impuesta: Dos penas de seis años y un día de prisión mayor, por un lado, y de tres años, seis meses y veintiún días de prisión correccional, por otro.

Conmutada por: dos años y cuatro meses de prisión correccional y seis meses de arresto mayor, respectivamente.

Beneficiaria: Adoración Bragado Morillo

Motivo por el que se justifica: "Considerando que de la rigurosa aplicación de los preceptos legales resultan notoriamente excesivas las penas impuestas con relación al daño causado y grado de malicia que revela".

$\mathrm{N}^{\circ} 40$

Fecha de publicación: 15 de abril de 1924

Órgano del que procede la petición: El propio interesado

Delito cometido: Homicidio

Pena impuesta: Ocho años y un día de prisión mayo

Conmutada por: Seis años de destierro

Beneficiario: José Gómez Martínez

Motivo por el que se justifica: "Considerando las circunstancias que en el hecho concurrieron, así como el carácter social que reviste".

$\mathrm{N}^{\circ} 41$

Fecha de publicación: 20 de abril de 1924

Órgano del que procede la petición: Sin especificar.

Delito cometido: Insulto de obra a superior causando muerte

Pena impuesta: Pena de muerte impuesta por la Sala de Justicia del Consejo Supremo de Guerra y Marina

Conmutada por: Reclusión militar perpetua, quedando subsistentes las accesorias que determina la parte dispositiva de la sentencia.

Beneficiario: Francisco Rodriguez Morales, carabinero de 1a Comandancia de Estepona.

Motivo por el que se justifica: Tradición religiosa del acto de la adoración de la Santa Cruz: "Teniendo en cuenta que los Reyes de España han solemnizado siempre el día de hoy, en que la Iglesia conmemora el misterio de la redención del género humano, con el indulto de algunos reos condenados a la última pena, piadosa costumbre que es muy grata a Mi Corazón continuar observando”. 
$\mathrm{N}^{\mathrm{o}} 42$

Fecha de publicación: 22 de abril de 1924

Órgano del que procede la petición: Sin especificar.

Delito cometido: Asesinato y parricidio

Pena impuesta: Pena de muerte.

Conmutada por: Cadena y prisión perpetuas, respectivamente, con sus accesorias.

Beneficiarios: Gumersindo Losada Fida1go y Francisca André Cuquejo

Motivo por el que se justifica: Tradición religiosa del acto de la adoración de la cruz: "Considerando que los Reyes de España han solemnizado siempre el día de hoy, en que la Iglesia conmemora Augusto Misterio de la Redención del Género humano con el perdón de algunos reos sentenciados a la última pena, piadosa costumbre que es muy grata a Mi corazón seguir observando”.

$\mathrm{N}^{\circ} 43$

Fecha de publicación: 22 de abril de 1924

Órgano del que procede la petición: Sin especificar.

Delito cometido: Parricidio

Pena impuesta: Pena de muerte.

Conmutada por: Cadena perpetua con sus accesorias.

Beneficiario: Pablo Mendaza y Gómez de Segura

Motivo por el que se justifica: Tradición religiosa del acto de la adoración de la cruz: "Considerando que los Reyes de España han solemnizado siempre el día de hoy, en que la Iglesia conmemora Augusto Misterio de la Redención del Género humano con el perdón de algunos reos sentenciados a la última pena, piadosa costumbre que es muy grata a Mi corazón seguir observando".

$\mathrm{N}^{\circ} 44$

Fecha de publicación: 22 de abril de 1924

Órgano del que procede la petición: Sin especificar.

Delito cometido: Asesinato

Pena impuesta: Pena de muerte.

Conmutada por: Cadena perpetua con sus accesorias.

Beneficiario: José Manuel Hernández Ramos

Motivo por el que se justifica: Tradición religiosa del acto de la adoración de la cruz: "Considerando que los Reyes de España han solemnizado siempre el día de hoy, en que la Iglesia conmemora Augusto Misterio de la Redención del Género humano con el perdón de algunos reos sentenciados a la última pena, piadosa costumbre que es muy grata a Mi corazón seguir observando”.

$\mathrm{N}^{\circ} 45$

Fecha de publicación: 22 de abril de 1924

Órgano del que procede la petición: Sin especificar.

Delito cometido: Asesinato

Pena impuesta: Pena de muerte.

Conmutada por: Cadena perpetua con sus accesorias.

Beneficiario: Paulino Moreda García

Motivo por el que se justifica: Tradición religiosa del acto de la adoración de la cruz: "Considerando que los Reyes de España han solemnizado siempre el día de hoy, en que la Iglesia conmemora Augusto Misterio de la Redención del Género 
humano con el perdón de algunos reos sentenciados a la última pena, piadosa costumbre que es muy grata a Mi corazón seguir observando".

\section{$\mathrm{N}^{\circ} 46$}

Fecha de publicación: 22 de abril de 1924

Órgano del que procede la petición: Sin especificar.

Delito cometido: Robo con homicidio

Pena impuesta: Pena de muerte.

Conmutada por: Cadena perpetua con sus accesorias.

Beneficiario: Juan López Barrera

Motivo por el que se justifica: Tradición religiosa del acto de la adoración de la cruz: "Considerando que los Reyes de España han solemnizado siempre el día de hoy, en que la Iglesia conmemora Augusto Misterio de la Redención del Género humano con el perdón de algunos reos sentenciados a la última pena, piadosa costumbre que es muy grata a Mi corazón seguir observando".

\section{$\mathrm{N}^{\circ} 47$}

Fecha de publicación: 22 de abril de 1924

Órgano del que procede la petición: Sin especificar.

Delitos cometidos: Dos asesinatos

Pena impuesta: Pena de muerte.

Conmutada por: Cadena perpetua con sus accesorias.

Beneficiario: José Martín Pérez,

Motivo por el que se justifica: Tradición religiosa del acto de la adoración de la cruz: "Considerando que los Reyes de España han solemnizado siempre el día de hoy, en que la Iglesia conmemora Augusto Misterio de la Redención del Género humano con el perdón de algunos reos sentenciados a la última pena, piadosa costumbre que es muy grata a Mi corazón seguir observando".

\section{$\mathrm{N}^{\circ} 48$}

Fecha de publicación: 22 de abril de 1924

Órgano del que procede la petición: Sin especificar.

Delito cometido: Parricidio

Pena impuesta: Pena de muerte.

Conmutada por: Cadena perpetua con sus accesorias.

Beneficiario: Nicanor Pérez y Pérez

Motivo por el que se justifica: Tradición religiosa del acto de la adoración de la cruz: "Considerando que los Reyes de España han solemnizado siempre el día de hoy, en que la Iglesia conmemora Augusto Misterio de la Redención del Género humano con el perdón de algunos reos sentenciados a la última pena, piadosa costumbre que es muy grata a Mi corazón seguir observando".

$\mathrm{N}^{\circ} 49$

Fecha de publicación: 22 de abril de 1924

Órgano del que procede la petición: Fiscalía

Delito cometido: Varios delitos de hurto

Pena impuesta: Pena de muerte.

Conmutada por: Indulto total

Beneficiario: Fernando Talavera Ramírez 
Motivo por el que se justifica: "Considerando que según consta del referido expediente las actuaciones judiciales practicadas después de ejecutada la sentencia condenatoria dan fundamento racional para juzgar que se cometió en ellas error en persona. Considerando que desde el momento en que no hay certidumbre de que el penado sea el verdadero culpable, exige la justicia que no continúe sufriendo la condena; teniendo presente lo dispuesto en la ley antes citada, que establece reglas para el ejercicio de la gracia de indulto; en armonía con el informe de la Sala sentenciadora y con lo consultado por la Comisión permanente del Consejo de Estado, y conformándome con el parecer el Presidente del Directorio Militar, dé acuerdo con éste".

\section{$\mathrm{N}^{\circ} 50$}

Fecha de publicación: 22 de abril de 1924

Órgano o persona de la que procede la petición: El propio interesado.

Delito cometido: Asesinato

Pena impuesta: Dos años, cuatro meses y un día de prisión correccional

Conmutada por: Destierro la mitad de la pena impuesta

Beneficiario: Diego Moral Moreno

Motivo por el que se justifica: "Considerando las pruebas de arrepentimiento del penado y su buena conducta en la prisión, así como la que con anterioridad venía observando".

\section{$\mathrm{N}^{\mathrm{0}} 51$}

Fecha de publicación: 22 de abril de 1924

Órgano o personas de las que procede la petición: El propio interesado y autoridades y vecinos de Alcalá del Río.

Delito cometido: Atentado

Pena impuesta: Dos años, once meses y once días de prisión correccional

Conmutada por: Destierro el resto de la pena que le falta por cumplir.

Beneficiario: Felipe Velázquez Jiménez

Motivo por el que se justifica: "Considerando la naturaleza del delito, el estado de embriaguez del penado al cometerlo y que la parte ofendida otorga su perdón”.

\section{$\mathrm{N}^{\circ} 52$}

Fecha de publicación: 22 de abril de 1924

Órgano o persona de la que procede la petición: El propio interesado.

Delito cometido: Tres delitos de robo

Pena impuesta: Tres penas de dos años, cuatro meses y un día de presidio correccional.

Conmutada por: Destierro el resto de la pena que le falta por cumplir.

Beneficiario: Gabriel Triay Fortuny

Motivo por el que se justifica: "Considerando la naturaleza y circunstancias del hecho delictivo y el tiempo de cumplimiento de condena que lleva el penado".

\section{$\mathrm{N}^{\circ} 53$}

Fecha de publicación: 22 de abril de 1924

Órgano o persona de la que procede la petición: El propio interesado.

Delito cometido: Hurto

Pena impuesta: Dos años, cuatro meses y un día de presidio correccional

Conmutada por: Destierro el resto de la pena que le falta por cumplir. 
Beneficiario: José Pérez Morales

Motivo por el que se justifica: "Considerando las circunstancias especiales que concurrieron en el delito; que la parte ofendida no se opone al indulto, y el tiempo de cumplimiento de condena que lleva el penado".

$\mathrm{N}^{\circ} 54$

Fecha de publicación: 1 de mayo de 1924

Órgano o persona de la que procede la petición: El propio interesado

Delito cometido: Homicidio

Pena impuesta: Seis años y un día de prisión mayor

Se le conmuta: La mitad de la pena

Beneficiario: José Granés y Sangrá

Motivo por el que se justifica: "Considerando las circunstancias que en el hecho concurrieron y la ejemplar conducta que viene observando el reo".

$\mathrm{N}^{\mathrm{o}} 55$

Fecha de publicación: 1 de mayo de 1924

Órgano o persona de la que procede la petición: Juana Ollero del Castillo (esposa del condenado)

Delito cometido: Homicidio

Pena impuesta: Doce años y un día de reclusión temporal

Conmutada por: Ocho años de prisión mayor

Beneficiario: Bonifacio Juan Bellot de Lucas

Motivo por el que se justifica: "Considerando las circunstancias que dieron origen al hecho delictivo y la buena conducta y pruebas de arrepentimiento de que da muestras el penado".

$\mathrm{N}^{\circ} 56$

Fecha de publicación: 1 de mayo de 1924

Órgano o persona de la que procede la petición: El propio interesado

Delitos cometidos: Tres de estafa

Pena impuesta: Un año, ocho meses y veintiún días de presidio correccional y cuatro meses y un día de arresto mayor

Se le conmuta: El resto de la pena que se halla cumpliendo y la de arresto mayor

Beneficiario: Francisco Bernabé Sarta Olalla

Motivo por el que se justifica: "Considerando que la parte ofendida ha perdonado y renuncia a la indemnización, y la buena conducta que viene observando el penado".

$\mathrm{N}^{\circ} 57$

Fecha de publicación: 1 de mayo de 1924

Órgano o persona de la que procede la petición: Francisco Lara Cayuela (padre del condenado)

Delitos cometidos: Dos homicidios

Penas impuestas: Dos de doce años y un día de reclusión temporal

Conmutada por: Destierro el resto de las penas que le faltan por cum

Beneficiario: José Lara Megías

Motivo por el que se justifica: "Considerando las pruebas de arrepentimiento de que viene dando muestras el penado, su buena conducta y el tiempo que lleva de cumplimiento de condena". 
$\mathrm{N}^{\circ} 58$

Fecha de publicación: 16 de mayo de 1924

Órgano o personas de las que procede la petición: varias Autoridades y vecinos del pueblo de Alfacar, el propio interesado y Encarnación Vílchez Gómez, su esposa

Delito cometido: Lesiones graves

Pena impuesta: Dos años, cuatro meses y un día de prisión correccional

Conmutada por: Destierro del resto de la pena que le falta por cumplir

Beneficiario: Antonio Ruiz Zúñiga

Motivo por el que se justifica: "Considerando que la parte ofendida ha otorgado su perdón y la buena conducta que viene observando el penado".

$\mathrm{N}^{\circ} 59$

Fecha de publicación: 24 de mayo de 1924

Órgano del que procede la petición: Sala de lo Criminal del Tribunal Supremo

Delito cometido: Asesinato

Pena impuesta: Muerte

Conmutada por: Cadena perpetua, con sus accesorias

Beneficiario: José Manuel Sánchez Colmenero

Motivo por el que se justifica: "Considerando las circunstancias que concurren en el presente caso; haciendo uso de la prerrogativa que me concede el número $3^{\circ}$ del artículo 54 de 1 a Constitución vigente".

$\mathrm{N}^{\circ} 60$

Fecha de publicación: 24 de mayo de 1924

Órgano o personas de las que procede la petición: María Delgado Pérez (esposa del condenado) y Manuel Borrero Delgado (hijo del condenado)

Delito cometido: Asesinato

Pena impuesta: Cadena perpetua

Conmutada por: veinte años de cadena temporal

Beneficiario: Francisco Borrero Delgado

Motivo por el que se justifica: "Considerando las circunstancias del hecho delictivo y la buena conducta que viene observando el penado".

$\mathrm{N}^{\circ} 61$

Fecha de publicación: 24 de mayo de 1924

Órgano o persona de la que procede la petición: El propio interesado

Delito cometido: Homicidio

Pena impuesta: Catorce años, ocho meses y un día de reclusión temporal

Conmutada por: Destierro el resto de la pena que le falta por cumplir

Beneficiario: Isidro Tejera Sánchez

Motivo por el que se justifica: "Considerando la conducta intachable que viene observando el penado, por la que se le ha distinguido con premios, y las pruebas de arrepentimiento de que da muestras".

$\mathrm{N}^{\circ} 62$

Fecha de publicación: 24 de mayo de 1924

Órgano o persona de la que procede la petición: El propio interesado

Delitos cometidos: Tres de hurto 
Penas impuestas: Tres de cuatro años, dos meses y un dia de presidio correccional.

Se le conmuta: El resto de la pena que le queda por cumplir

Beneficiario: José Perea Jiménez

Motivo por el que se justifica: "Considerando que la parte perjudicada no se opone al indulto y la ejemplar conducta y muestras de arrepentimiento de que da prueba el penado".

$\mathrm{N}^{\circ} 63$

Fecha de publicación: 24 de mayo de 1924

Órgano o persona de la que procede la petición: El propio interesado

Delito cometido: Disparo y lesiones graves

Pena impuesta: Dos años, ocho meses y veintidós dias de prisión correccional

Conmutada por: Destierro del resto de la pena que le queda por cumplir

Beneficiario: Salvador Terrés Pérez ${ }^{82}$

Motivo por el que se justifica: "Considerando que la parte ofendida ha otorgado su perdón y la buena conducta y pruebas de arrepentimiento de que da muestras el penado".

$\mathrm{N}^{\circ} 64$

Fecha de publicación: 24 de mayo de 1924

Órgano o persona de la que procede la petición: El propio interesado

Delito cometido: Estafa

Pena impuesta: Un año, ocho meses y veintiún días de presidio correccional

Conmutada por: Destierro el resto de la pena que le queda por cumplir

Beneficiario: Sabino Aguirre Iríbar

Motivo por el que se justifica: "Considerando las circunstancias del delito y la intachable conducta, que viene observando el penado"

$\mathrm{N}^{\circ} 65$

Fecha de publicación: 31 de mayo de 1924

Órgano del que procede la petición: No se especifica

Delito cometido: No se especifica

Pena impuesta: Pena de muerte (impuesta por Consejo de guerra celebrado en Melilla, aprobado por la Autoridad Judicial militar de dicho territorio)

Conmutada por: Reclusión militar perpetua (dejando subsistentes todos los demás pronunciamientos contenidos en la sentencia)

Beneficiario: Antonio Pérez García

82 Gazeta del 25 de mayo de 1924: "Habiéndose padecido error de copia en el Real decreto de indulto referente a Salvador Terrés Pérez, publicado en la GACETA DE MADRID del día 24 del mes actual se inserta a continuación debidamente rectificado. Visto el expediente instruido con motivo de instancia elevada por Salvador Terrés Pérez, en súplica de que se le indulte o conmute por destierro el resto de la pena de dos años, ocho meses y veintidós dias de prisión correccional a que fué condenado por la Audiencia de Almería en causa por delito de disparo y lesiones graves. Considerando que la parte ofendida ha otorgado su perdón, y la buena conducta y muestras de arrepentimiento de que da muestras el penado... Vengo en conmutar por destierro el resto de la pena que le falta por cumplir a Salvador Terrés Pérez, y que le fue impuesta en la causa y por el delito mencionados". 
Motivo por el que se justifica: "Usando de la prerrogativa que me confiere el número $3^{\circ}$ del artículo 54 de la Constitución de la Monarquía; a propuesta e1 Jefe del Gobierno, Presidente del Directorio Militar, y de acuerdo con éste...”.

$\mathrm{N}^{\circ} 66$

Fecha de publicación: 5 de junio de 1924

Órgano o persona de la que procede la petición: El propio interesado

Delito cometido: Disparo y lesiones

Pena impuesta: Tres años, cuatro meses y ocho dias de prisión correccional

Conmutada: La mitad de la pena

Beneficiario: Fabián Luis Garay e Isusi

Motivo por el que se justifica: "Considerando las circunstancias que en el hecho concurrieron, 1a buena conducta y arrepentimiento del penado y que la parte agraviada no se opone al indulto".

\section{$\mathrm{N}^{\circ} 67$}

Fecha de publicación: 5 de junio de 1924

Órgano del que procede la petición: Sala de lo Criminal del Tribunal Supremo

Delito cometido: Disparo de arma de fuego

Pena impuesta: Un año, ocho meses y un día de prisión correccional

Conmutada por: Seis meses y un dia de igual prisión

Beneficiario: Jaime Pagés Albert

Motivo por el que se justifica: "Considerando que de la rigurosa aplicación de los preceptos legales resulta notoriamente excesiva la pena impuesta con relación al daño causado y grado de malicia que revela".

$\mathrm{N}^{\circ} 68$

Fecha de publicación: 5 de junio de 1924

Órgano del que procede la petición: Audiencia de Palencia

Delito cometido: Hurto

Pena impuesta: Cuatro años, dos meses y un día de prisión correccional

Conmutada por: Un año de igual prisión

Beneficiario: Lucila Aparicio Ibáñez

Motivo por el que se justifica: "Considerando que de la rigurosa aplicación de los preceptos legales resulta notoriamente excesiva la pena impuesta en relación al daño causado y grado de malicia que revela".

$\mathrm{N}^{\circ} 69$

Fecha de publicación: 1 de agosto de 1924

Órgano o persona de la que procede la petición: El propio interesado

Delito cometido: Homicidio

Pena impuesta: Ocho años y un día de prisión mayor

Conmutada por: Igual tiempo de destierro el resto de la pena que le falta por cumplir

Beneficiario: Christian Hugo Nielsen

Motivo por el que se justifica: "Considerando las circunstancias que concurrieron en el delito y la buena conducta que observa el penado". 
$\mathrm{N}^{\mathrm{o}} 70$

Fecha de publicación: 1 de agosto de 1924

Órgano del que procede la petición: Audiencia de Granada

Delito cometido: Falsedad en documento público,

Pena impuesta: Catorce años, ocho meses y un dia de cadena temporal con accesorias

Conmutada por: Dos años, cuatro meses y un día de destierro a 25 kilómetros de Guadix

Beneficiario: Enrique Teba Fernández

Motivo por el que se justifica: "Considerando que de la rigurosa aplicación de los preceptos legales, resulta notoriamente excesiva la pena impuesta con relación al daño causado y grado de malicia que revela".

$\mathrm{N}^{\mathrm{o}} 71$

Fecha de publicación: 8 de agosto de 1924

Órgano del que procede la petición: Sala de lo Criminal del Tribunal Supremo

Delito cometido: Robo con homicidio

Pena impuesta: Muerte

Conmutada por: Cadena perpetua con sus accesorias

Beneficiario: Antonio Garcia Santamaria

Motivo por el que se justifica: "Considerando las circunstancias que concurren en el presente caso; haciendo uso de la prerrogativa que me concede el número 3, del artículo 54 de la Constitución vigente".

$\mathrm{N}^{\circ} 72$

Fecha de publicación: 16 de septiembre de 1924

Órgano o persona de la que procede la petición: El propio interesado

Delito cometido: Homicidio por imprudencia temeraria

Pena impuesta: Un año y un día de prisión correccional

Conmutada por: Destierro del resto de la pena que le queda por cumplir

Beneficiario: José Fernández Mira

Motivo por el que se justifica: "Considerando la naturaleza del hecho delictivo, la buena conducta del penado y que la parte agraviada ha otorgado su perdón".

$\mathrm{N}^{\mathrm{o}} 73$

Fecha de publicación: 3 de octubre de 1924

Órgano del que procede la petición: Audiencia de Barcelona

Delito cometido: Hurto

Pena impuesta: Cuatro años, nueve meses y once dias de presidio correccional

Se le indulta: De la pena que le queda por cumplir

Beneficiario: Lucas Morales Ortega

Motivo por el que se justifica: "Considerando que de la rigurosa aplicación de los preceptos legales resulta notoriamente excesiva la pena impuesta con relación al daño causado y grado de malicia que revela".

$\mathrm{N}^{\mathrm{o}} 74$

Fecha de publicación: 3 de octubre de 1924

Órgano del que procede la petición: Audiencia de Lérida

Delito cometido: Falsedad 
Penas impuestas: Una de doce años y un día de cadena temporal (Enrique Minguell) y otra de catorce años, ocho meses y un día de igual clase de cadena (Antonio Minguet).

Conmutada por: Cuatro y seis años de presidio correccional (a cada uno).

Beneficiarios: Enrique Minguell Riera y Antonio Minguet Benet

Motivo por el que se justifica: "Considerando que de la rigurosa aplicación de los preceptos legales resultan notoriamente excesivas las penas impuestas con relación, al daño causado y grado de malicia que revelan".

\section{$\mathrm{N}^{\mathrm{o}} 75$}

Fecha de publicación: 3 de octubre de 1924

Órgano del que procede la petición: Audiencia de Cáceres

Delitos cometidos: Dos de estafa (uno consumado y otro en grado de tentativa)

Penas impuestas: Nueve años, ocho meses y veintidós dias de presidio mayor y de ocho años y un día de igual presidio (respectivamente).

Conmutada por: Cuatro años, dos meses y un día igual presidio correccional por el delito consumado y dos años, cuatro meses y un día igual presidio por el castigado en grado de tentativa.

Beneficiarios: Teodoro Badorrey Miranda y José Ruiz López

Motivo por el que se justifica: "Considerando que de la rigurosa aplicación de los preceptos legales resultan notoriamente excesivas las penas impuestas con relación al daño, causado y grado de malicia que revela".

\section{$\mathrm{N}^{\mathrm{o}} 76$}

Fecha de publicación: 7 de octubre de 1924

Órgano del que procede la petición: Audiencia de Palma

Delito cometido: Contrabando

Pena impuesta: Dos años, dos meses y un día de prisión correccional y multa de 18000 pesetas

Conmutada por: Seis meses y un día de prisión correccional y multa de 7800 pesetas

Beneficiario: Miguel Riera Pons

Motivo por el que se justifica: "Considerando que de la rigurosa aplicación de los preceptos legales resulta notoriamente excesiva la pena impuesta, con relación al daño causado y grado de malicia que revela".

\section{$\mathrm{N}^{\mathrm{o}} 77$}

Fecha de publicación: 7 de octubre de 1924

Órgano del que procede la petición: Audiencia de Cuenca

Delito cometido: Malversación de caudales públicos

Pena impuesta: Seis años y un día de presidio mayor

Conmutada por: Cuatro años de destierro a 25 kilómetros del lugar en que delinquió.

Beneficiario: Juan Bautista Alarcón Barón

Motivo por el que se justifica: "Considerando que de la rigurosa aplicación de los preceptos legales resulta notoriamente excesiva la pena impuesta, con relación al daño causado y grado de malicia que revela”. 
$\mathrm{N}^{\mathrm{o}} 78$

Fecha de publicación: 18 de octubre de 1924

Órgano del que procede la petición: Sala de lo Criminal del Tribunal Supremo

Delito cometido: Homicidio

Pena impuesta: Ocho años y un día de prisión mayor

Se le indulta de: La pena que le resta por cumplir

Beneficiario: Francisco Garrido Basilio

Motivo por el que se justifica: "Considerando que de la rigurosa aplicación de los preceptos legales resulta notoriamente excesiva la pena impuesta con relación al grado de malicia y circunstancias que concurrieron en el hecho".

$\mathrm{N}^{\mathrm{o}} 79$

Fecha de publicación: 25 de octubre de 1924

Órgano o persona de la que procede la petición: El propio interesado (por conducto y con el asentimiento del Presidente de la Comisión asesora de libertad condicional, en concepto de penado liberto)

Delito cometido: Asesinato

Pena impuesta: Inhabilitación absoluta perpetua para cargos públicos que, como accesoria de la de cadena perpetua que ha cumplido

Se le indulta de: La pena de inhabilitación absoluta perpetua para cargos públicos (que, como accesoria de la de cadena perpetua, le fue impuesta en la causa y por el delito mencionados)

Beneficiario: Cipriano Diego Bernardo

Motivo por el que se justifica: "Considerando la buena conducta y arrepentimiento del penado durante el tiempo de cumplimiento de su condena, y que mantiene posteriormente".

$\mathrm{N}^{\circ} 80$

Fecha de publicación: 25 de octubre de 1924

Órgano del que procede la petición: Audiencia de Huesca

Delito cometido: Robo

Pena impuesta: Dos años, once meses y once días de presidio correccional

Se le indulta: Del resto de la pena que la falta por cumplir

Beneficiario: Emeterio Beltrán Rasal

Motivo por el que se justifica: "Considerando que de la rigurosa ap1icación de los preceptos legales resulta notoriamente excesiva la pena impuesta, con relación al daño causado y grado de malicia que revela, y el tiempo que lleva de cumplimiento de condena".

\section{$\mathrm{N}^{\circ} 81$}

Fecha de publicación: 31 de octubre de 1924

Órgano o personas de las que procede la petición: hijos del condenado y varias autoridades y vecinos de Tetuán

Delito cometido: Homicidio

Pena impuesta: Trece años de reclusión temporal

Se le indulta: Del resto de la pena que la falta por cumplir

Beneficiario: Juan Chaves Romero

Motivo por el que se justifica: "Considerando las circunstancias que concurrieron en el hecho delictivo, la buena conducta y arrepentimiento del penado, el tiempo 
que lleva de cumplimiento de su condena y que no le han alcanzado los beneficios de los Reales decretos de amnistía e indulto general de 1919 y 1924".

$\mathrm{N}^{\circ} 82$

Fecha de publicación: 6 de noviembre de 1924

Órgano o persona de la que procede la petición: Manuel Alonso Crespo (esposo de la condenada)

Delito cometido: Injurias graves

Pena impuesta: Un año, ocho meses y veintiún dias de destierro

Se le indulta: Del resto de la pena que la falta por cumplir

Beneficiaria: Amalia de la Resurrección Fernández

Motivo por el que se justifica: "Considerando que la parte agraviada ha otorgado su perdón".

$\mathrm{N}^{\circ} 83$

Fecha de publicación: 14 de noviembre de 1924

Órgano del que procede la petición: Audiencia de Madrid

Delito cometido: Malversación

Pena impuesta: Tres años, seis meses y veintiún días de prisión correccional

Se le indulta: Del resto de la pena que la falta por cumplir

Beneficiaria: María Gesto Martínez

Motivo por el que se justifica: "Considerando que de la rigurosa aplicación de los preceptos legales resulta notoriamente excesiva la pena impuesta con relación al daño causado y grado de malicia que revela y el tiempo de condena que lleva cumplido".

$\mathrm{N}^{\circ} 84$

Fecha de publicación: 14 de noviembre de 1924

Órgano del que procede la petición: Sala de lo Criminal del Tribunal Supremo

Delito cometido: Malversación de caudales públicos

Pena impuesta: Tres años, seis meses y veintiún días de presidio correccional

Conmutada por: Cuatro años de suspensión de cargo público y multa de 80 pesetas

Beneficiarios: Manuel Adín Avendaño 83 y Ubaldo Pérez Aguirre

Motivo por el que se justifica: "Considerando que de la rigurosa aplicación de los preceptos legales resultan notoriamente excesivas las penas impuestas con relación al daño causado y grado de malicia que revelan".

83 "Habiéndose padecido un error de copia en el Real decreto inserto en la GACETA DE MADRID del dia 14 del mes actual, se publica a continuación, debidamente rectificado. Visto el expediente instruido con motivo de elevada por la Sala de lo Criminal del Tribunal Supremo, proponiendo, con arreglo al artículo $2^{\circ}$, del Código penal, que las penas de tres años, seis meses y veintiún días de presidio correcciona1, impuestas a Manuel Adín Avendaño y Ubaldo Pérez Aguirre, por la Audiencia de Pamplona, por delito de malversación de caudales públicos, sean conmutadas por las de dos años y un día de suspensión de sus cargos y multa de 80 pesetas. Considerando que de la rigurosa aplicación de los preceptos legales resultan notoriamente excesivas las penas impuestas en relación al delito causado y grado de malicia que revela... Vengo en conmutar por las de cuatro años de suspensión de cargo público y multa de. 80 pesetas, las penas impuestas a Manuel Adín Avendaño y Ubaldo Pérez Aguirre, en la causa y por el delito mencionados...". 
$\mathrm{N}^{\mathrm{o}} 85$

Fecha de publicación: 22 de noviembre de 1924

Órgano o persona de la que procede la petición: José María Durán Balcells, procurador, en nombre y representación del condenado.

Delito cometido: Disparo y lesiones.

Pena impuesta: Dos años, diez meses y dos días de prisión correccional

Se le indulta: Del resto de la pena que la falta por cumplir

Beneficiario: Fulgencio Cristóbal José Solé Grau

Motivo por el que se justifica: "Considerando que el agraviado ha otorgado su perdón, habiendo sido en parte indemnizado, la buena conducta y pruebas de arrepentimiento del penado y el poco tiempo que le resta de condena”.

$\mathrm{N}^{\circ} 86$

Fecha de publicación: 22 de noviembre de 1925

Órgano del que procede la petición: Comandante general de Ceuta

Delito cometido: No se especifica

Pena impuesta: No se especifica. Sólo se indica que el condenado ha cumplido las tres cuartas partes de su condena.

Conmutada por: Libertad condicional

Beneficiario: Ali Ben Yilali Fatma

Motivo por el que se justifica: "Visto lo dispuesto en el artículo $5^{\circ}$ de la ley de 28 de Diciembre de 1918, dictada para la aplicación en el fuero de guerra, la de 23 de Julio de 1914 y de acuerdo con lo informado por el Consejo Supremo de Guerra y Marina...".

$\mathrm{N}^{\circ} 87$

Fecha de publicación: 10 de diciembre de 1924

Órgano del que procede la petición: Consejo Supremo de Guerra y Marina

Delito cometido: Deserción

Pena impuesta: Cuatro años de prisión militar correccional

Conmutada por: Un año de igual prisión (quedando subsistente lo demás que determina la sentencia).

Beneficiario: Victoriano Aranda Gabete (soldado del Regimiento de Infantería Galicia $\mathrm{n}^{\circ}$ 19).

Motivo por el que se justifica: "Circunstancias especiales del caso".

$\mathrm{N}^{\circ} 88$

Fecha de publicación: 12 de diciembre de 1924

Órgano del que procede la petición: Sala de vacaciones del Tribunal Supremo

Delito cometido: Robo con homicidio

Pena impuesta: Muerte

Conmutada por: Cadena perpetua, con las accesorias

Beneficiario: Ceferino Camuñas Fermoselle

Motivo por el que se justifica: "Considerando las circunstancias que concurren en el presente caso".

$\mathrm{N}^{\circ} 89$

Fecha de publicación: 18 de diciembre de 1924

Órgano del que procede la petición: Sala de lo Criminal del Tribunal Supremo

Delito cometido: Robo con homicidio 
Pena impuesta: Muerte

Conmutada por: Cadena perpetua, con las accesorias correspondientes

Beneficiario: José Antonio Larios Morales

Motivo por el que se justifica: "Considerando las circunstancias que concurren en el presente caso".

$\mathrm{N}^{\circ} 90$

Fecha de publicación: 23 de diciembre de 1924

Órgano o persona de la que procede la petición: El propio interesado

Delito cometido: Falsificación de documento privado

Pena impuesta: Un año, ocho meses y veintiún días de presidio correccional

Conmutada por: Destierro el resto de la pena que le falta cumplir

Beneficiario: Manuel Martín Gascón

Motivo por el que se justifica: "Considerando que el hecho delictivo no causó perjuicio alguno, así como los buenos antecedentes y arrepentimiento del penado".

$\mathrm{N}^{\circ} 91$

Fecha de publicación: 23 de diciembre de 1924

Órgano del que procede la petición: Audiencia de Valladolid

Delito cometido: Estafa

Pena impuesta: Doce años, cuatro meses y un día de presidio correccional

Conmutada por: Seis meses de arresto mayor

Beneficiario: Enrique Sánchez González

Motivo por el que se justifica: "Considerando que de la rigurosa aplicación de los preceptos legales, resulta notoriamente excesiva la pena impuesta con relación al daño causado y grado de malicia que revela".

$\mathrm{N}^{\circ} 92$

Fecha de publicación: 3 de enero de 1925

Órgano o personas de las que procede la petición: Los propios interesados

Delito cometido: Hurto

Pena impuesta: Dos años, once meses y once días de presidio correccional

Conmutada por: Igual tiempo de destierro del resto de las penas que les falta por cumplir' (a Juan Cesáreo Bermejo Leal, Ángel Saturnino Vecino Pulido e Ildefonso Demetrio Romero Hernández) y del resto de la suya a Luis Marcelo Gaspar

Beneficiarios: Juan Cesáreo Bermejo Leal, Luis Marcelo Gaspar, Ángel Saturnino Vecino Pulido e Ildefonso Demetrio Romero Hernández

Motivo por el que se justifica: "Considerando la índole del delito, que no produjo alarma ni es frecuente en el territorio de aquella Audiencia, el perdón de la parte ofendida, la buena conducta de los penados y especialmente con respecto a Luis Marcelo Gaspar, su mal estado de salud".

$\mathrm{N}^{\circ} 93$

Fecha de publicación: 3 de enero de 1925

Órgano del que procede la petición: Sala de lo Criminal del Tribunal Supremo

Delito cometido: Homicidio

Pena impuesta: Doce años y un día de reclusión temporal

Conmutada por: Un año de prisión correccional

Beneficiario: Andrés Beato Martín 
Motivo por el que se justifica: "Considerando que de la rigurosa aplicación de los preceptos legales, resulta notoriamente excesiva la pena impuesta con relación al daño causado y grado de malicia que revela".

$\mathrm{N}^{\circ} 94$

Fecha de publicación: 13 de enero de 1925

Órgano del que procede la petición: Sala de lo Criminal del Tribunal Supremo

Delito cometido: Parricidio

Pena impuesta: Muerte

Conmutada por: Reclusión perpetua con las accesorias correspondientes.

Beneficiaria: Manuela Arias Álvarez

Motivo por el que se justifica: "Considerando las circunstancias que concurren en el presente caso".

$\mathrm{N}^{\circ} 95$

Fecha de publicación: 22 de enero de 1925

Órgano o persona de la que procede la petición: El propio interesado

Delito cometido: Atentado

Pena impuesta: Dos años, cuatro meses y un día de prisión correccional y multa de 250 pesetas

Conmutada por: Igual tiempo de destierro

Beneficiario: Martín Huete Gasco

Motivo por el que se justifica: "Considerando que la parte agraviada no se opone al indulto, la buena conducta del penado y las circunstancias especialísimas que en el hecho concurrieron".

$\mathrm{N}^{\circ} 96$

Fecha de publicación: 5 de febrero de 1925

Órgano o persona de la que procede la petición: El propio interesado

Delito cometido: Falsedad en documento privado

Pena impuesta: Un año, ocho meses y veintiún días de presidio correccional

Conmutada por: Destierro el resto de la pena

Beneficiario: Gabriel Braulio Martín García

Motivo por el que se justifica: "Considerando que la parte agraviada no se opone al indulto, que no se ha ocasionado perjuicio alguno con el delito y que su comisión no revela perversidad ni maldad en el delincuente; teniendo asimismo en cuenta su buena conducta anterior y posterior al hecho delictivo".

$\mathrm{N}^{\circ} 97$

Fecha de publicación: 7 de febrero de 1925

Órgano o persona de la que procede la petición: El propio interesado

Delito cometido: Desacato

Pena impuesta: Un año, ocho meses y veintiún días de prisión correccional

Se le indulta: del resto de la pena que le falta por cumplir

Beneficiario: Eliseo Basilio Sánchez-Aparicio Nieto

Motivo por el que se justifica: "Considerando que la parte ofendida ha otorgado su perdón y la buena conducta y muestras de arrepentimiento del penado". 
$\mathrm{N}^{\circ} 98$

Fecha de publicación: 7 de febrero de 1925

Órgano o persona de la que procede la petición: El propio interesado

Delito cometido: Homicidio

Pena impuesta: Ocho meses y un día de prisión mayor

Conmutada por: Destierro el resto de la pena que te falta por cumplir

Beneficiario: José María Piñeiro González

Motivo por el que se justifica: "Considerando las especiales circunstancias que concurrieron en el hecho delictivo, la buena conducta y arrepentimiento del penado y que la parte agraviada no se opone al indulto".

No 99

Fecha de publicación: 7 de febrero de 1925

Órgano del que procede la petición: Ayuntamiento, autoridades y numerosos vecinos del pueblo Íllar

Delito cometido: Estafa

Pena impuesta: Un año, ocho meses y veintiún dias de presidio correccional

Conmutada por: Destierro del resto de la pena que falta por cumplir

Beneficiario: Francisco Campos Fernández

Motivo por el que se justifica: "Considerando la unanimidad con que las Autoridades y convecinos del penado solicitan su indulto y la buena conducta y arrepentimiento del mismo".

\section{$\mathrm{N}^{\mathrm{o}} 100$}

Fecha de publicación: 21 de febrero de 1925

Órgano del que procede la petición: Audiencia de Logroño

Delito cometido: Hurto

Pena impuesta: Dos años, cuatro meses y un día de presidio correcciona

Conmutada por: Cuatro meses y un día de arresto mayor

Beneficiario: Eusebio Anguiano Alamós

Motivo por el que se justifica: "Considerando que de la rigurosa aplicación de 1os preceptos legales resulta notoriamente excesiva la pena impuesta, con relación al daño causado y grado de malicia que revela”.

$\mathrm{N}^{\mathrm{o}} 101$

Fecha de publicación: 26 de febrero de 1925

Órgano o persona de la que procede la petición: Jesusa Torres Bernal (hija de la condenada)

Delito cometido: Lesiones graves

Pena impuesta: Tres años, cuatro meses y ocho días de prisión correcciona

Se le indulta de: La mitad de la pena que le fue impuesta

Beneficiaria: Gregoria Bernal Aznar

Motivo por el que se justifica: "Considerando las circunstancias que concurrieren en el hecho delictivo y las que han determinado que no le hayan podido ser aplicados los beneficios del indulto general de 4 de Julio último, así como el perdón de la parte ofendida”.

$\mathrm{N}^{\circ} 102$

Fecha de publicación: 11 de marzo de 1925

Órgano del que procede la petición: Audiencia de Córdoba 
Delito cometido: Hurto

Pena impuesta: Cuatro años, dos meses y un día de presidio correccional Conmutada por: Dos años, cuatro meses y un dia de presidio correccional Beneficiario: Benito Mora Collado (conocido también por Benito Castillo Mora) Motivo por el que se justifica: "Considerando que de la rigurosa aplicación de los preceptos legales resulta notoriamente excesiva la pena impuesta con relación al daño causado y grado de malicia que revela".

$\mathrm{N}^{\circ} 103$

Fecha de publicación: 21 de marzo de 1925

Órgano del que procede la petición: Sala de Justicia del Consejo Supremo de Guerra y Marina

Delito cometido: Robo con homicidio

Pena impuesta: Muerte

Conmutada por: Cadena perpetua, quedando subsistentes las accesorias que determina la parte dispositiva de la sentencia.

Beneficiarios: Antonio Devesa y José Aracil.

Motivo por el que se justifica: "excepcionales circunstancias que en este caso concurren".

$\mathrm{N}^{\circ} 104$

Fecha de publicación: 11 de abril de 1925

Órgano del que procede la petición: Sala de lo Criminal del Tribunal Supremo

Delito cometido: Parricidio

Pena impuesta: Muerte

Conmutada por: Reclusión perpetua con sus accesorias

Beneficiaria: María del Dolor Volante Bernabé

Motivo por el que se justifica: "Considerando que los Reyes de España han solemnizado siempre el dia de hoy, en que la Iglesia conmemora el Augusto Misterio de la Redención del Género humano, con el perdón de algunos reos sentenciados a la última pena, piadosa costumbre que es muy grato a Mi Corazón seguir observando".

$\mathrm{N}^{\mathrm{o}} 105$

Fecha de publicación: 11 de abril de 1925

Órgano del que procede la petición: Sala de lo Criminal del Tribunal Supremo

Delito cometido: Parricidio

Pena impuesta: Muerte

Conmutada por: Cadena perpetua con sus accesorias

Beneficiario: Pablo Arcos Sanz

Motivo por el que se justifica: "Considerando que los Reyes de España han solemnizado siempre el día de hoy, en que la Iglesia conmemora el Augusto Misterio de la Redención del Género humano, con el perdón de algunos reos sentenciados a la última pena, piadosa costumbre que es muy grato a Mi corazón seguir observando"

$\mathrm{N}^{\circ} 106$

Fecha de publicación: 11 de abril de 1925

Órgano del que procede la petición: Sala de lo Criminal del Tribunal Supremo

Delito cometido: Robo con homicidio 
Pena impuesta: Muerte

Conmutada por: Cadena perpetua con sus accesorias

Beneficiario: Rafael Jiménez Naranjo (a) 'Matasiete'

Motivo por el que se justifica: "Considerando que los Reyes de España han solemnizado siempre el día de hoy, en que la Iglesia conmemora el Augusto Misterio de la Redención del Género humano, con el perdón de algunos reos sentenciados a la última pena, piadosa costumbre que es muy grato a Mi Corazón seguir observando".

\section{$\mathrm{N}^{\mathrm{o}} 107$}

Fecha de publicación: 11 de abril de 1925

Órgano del que procede la petición: Sala de lo Criminal del Tribunal Supremo

Delito cometido: Robo con homicidio

Pena impuesta: Muerte

Conmutada por: Cadena perpetua con sus accesorias.

Beneficiario: Cándido Vallelado Muñoz

Motivo por el que se justifica: "Considerando que los Reyes de España han solemnizado siempre el día de hoy, en que la Iglesia conmemora el Augusto Misterio de la Redención del Género humano, con el perdón de algunos reos sentenciados a la última pena, piadosa costumbre que es muy grato a Mi Corazón seguir observando".

\section{$\mathrm{N}^{\mathrm{o}} 108$}

Fecha de publicación: 16 de abril de 1925

Órgano o persona de la que procede la petición: Baldomero Montoya (abogado defensor del condenado)

Delito cometido: Atentado

Pena impuesta: Dos años, cuatro meses y un día de prisión correccional

Conmutada por: Igual tiempo de destierro

Beneficiario: Luis Abril Lozano (ex Diputado a Cortes)

Motivo por el que se justifica: "Considerando las especiales circunstancias que en el hecho concurrieron y la buena conducta y arrepentimiento del penado".

$\mathrm{N}^{\circ} 109$

Fecha de publicación: 16 de abril de 1925

Órgano o persona de la que procede la petición: Francisco Pinel Fuentes (padre del condenado)

Delito cometido: Abusos deshonestos

Pena impuesta: Dos años, cuatro meses y un día de prisión correccional

Conmutada por: destierro del resto de la pena que le falta

Beneficiario: Francisco Pinel Sánchez

Motivo por el que se justifica: "Considerando las circunstancias especiales que concurrieron en el hecho y la buena conducta observada por el penado con anterioridad a la comisión del delito".

$\mathrm{N}^{\mathrm{o}} 110$

Fecha de publicación: 1 de mayo de 1925

Órgano persona de la que procede la petición: Francisca Rodríguez Escudero (esposa del condenado)

Delito cometido: Disparo de arma de fuego 
Pena impuesta: Seis meses y un día de prisión correccional

Conmutada por: Tres meses y once dias de arresto mayo

Beneficiario: Manuel Barrado Fernández Mela

Motivo por el que se justifica: "Considerando las circunstancias que en el hecho concurrieron, los buenos antecedentes del penado y su conducta en la prisión".

$\mathrm{N}^{\mathrm{o}} 111$

Fecha de publicación: 7 de mayo de 1925

Órgano o personas de las que procede la petición: Los propios interesados

Delito cometido: Homicidio

Pena impuesta: Diecisiete años, cuatro meses y un día de reclusión temporal

Conmutada por: Catorce años, ocho meses y un día de reclusión temporal

Beneficiarios: Modesto y Juan Francisco Sánchez Coca

Motivo por el que se justifica: "Considerando las circunstancias del hecho delictivo y la buena conducta y pruebas de arrepentimiento de los penados".

\section{$\mathrm{N}^{\mathrm{o}} 112$}

Fecha de publicación: 7 de mayo de 1925

Órgano o persona de la que procede la petición: Eduardo Barriobero y Herrán (abogado de la condenada)

Delito cometido: Hurto

Pena impuesta: Siete años, cuatro meses y un día de prisión mayor

Conmutada por: Igual tiempo de destierro el resto de la pena que le falta por cumplir

Beneficiaria: Josefa Jurado Pérez Parrón

Motivo por el que se justifica: "Considerando la buena conducta que viene observando la penada, su quebrantada salud, el tiempo que lleva de cumplimiento de condena y el perdón de la parte perjudicada".

\section{$\mathrm{N}^{\mathrm{o}} 113$}

Fecha de publicación: 30 de mayo de 1925

Órgano del que procede la petición: Audiencia de Murcia

Delito cometido: Lesa Majestad

Pena impuesta: Cuatro años, dos meses y un día de prisión correccional

Conmutada por: Igual tiempo de destierro

Beneficiario: Miguel Baldonado Pellicer

Motivo por el que se justifica: "Considerando que de la rigurosa aplicación de los preceptos legales resulta notoriamente excesiva la pena impuesta, con relación al daño causado y grado de malicia que revela”.

$\mathrm{N}^{\circ} 114$

Fecha de publicación: 7 de mayo de 1925

Órgano del que procede la petición: Audiencia de Sevilla

Delito cometido: Incendio

Pena impuesta: Catorce años, ocho meses y un día de cadena temporal

Conmutada por: Diez años de presidio mayor

Beneficiario: Manuel Alvarez González

Motivo por el que se justifica: "Considerando que de la rigurosa aplicación de los preceptos legales resulta notoriamente excesiva la pena impuesta, con relación al daño causado y grado de malicia que revela”. 


\section{$\mathrm{N}^{\mathrm{o}} 115$}

Fecha de publicación: 7 de mayo de 1925

Órgano del que procede la petición: Audiencia de Cuenca

Delito cometido: Alzamiento de bienes

Pena impuesta: Cuatro años, dos meses y un día de presidio correccional

Conmutada por: Igual tiempo de destierro

Beneficiario: Benito Buendia Baquero

Motivo por el que se justifica: "Considerando que de la rigurosa aplicación de los preceptos legales resulta notoriamente excesiva la pena impuesta, con relación al daño causado y grado de malicia que revela".

\section{$\mathrm{N}^{\mathrm{o}} 116$}

Fecha de publicación: 7 de mayo de 1925

Órgano del que procede la petición: Audiencia de Zaragoza

Delito cometido: Hurto

Pena impuesta: Dos años, cuatro meses y un día de presidio correccional

Se le indulta: Del resto de la pena que le falta cumplir

Beneficiario: Mariano Larrosa Gras

Motivo por el que se justifica: "Considerando que de la rigurosa aplicación de los preceptos legales resulta notoriamente excesiva la pena impuesta con relación al daño causado y grado de malicia que revela, y así también el tiempo de condena que lleva cumplido".

\section{$\mathrm{N}^{\mathrm{o}} 117$}

Fecha de publicación: 7 de mayo de 1925

Órgano del que procede la petición: Audiencia de Sevilla

Delito cometido: Parricidio

Pena impuesta: Cadena perpetua

Conmutada por: Catorce años, ocho meses y un día de cadena temporal

Beneficiario: Rafael Rodríguez González

Motivo por el que se justifica: "Considerando que de la rigurosa aplicación de los preceptos legales resulta notoriamente excesiva la pena impuesta, con relación al daño causado y grado de malicia qua revela".

$\mathrm{N}^{\circ} 118$

Fecha de publicación: 7 de mayo de 1925

Órgano del que procede la petición: Audiencia de Pamplona

Delito cometido: Parricidio

Pena impuesta: Cadena perpetua

Conmutada por: Doce años y un día de reclusión temporal

Beneficiario: Isaac López Larrión

Motivo por el que se justifica: "Considerando que de la rigurosa aplicación de los preceptos legales resulta notoriamente excesiva la pena impuesta con relación al daño causado y grado de malicia que revela".

\section{$\mathrm{N}^{\mathrm{o}} 119$}

Fecha de publicación: 5 de junio de 1925

Órgano o persona de la que procede la petición: Presentación Hierro Alarcón (madre del condenado)

Delito cometido: Homicidio 
Pena impuesta: Catorce años, ocho meses y un día de reclusión temporal Conmutada por: Seis años de prisión correccional

Beneficiario: Pedro Hierro Hier

Motivo por el que se justifica: "Considerando las circunstancias que concurrieron en el hecho delictivo, la buena conducta y arrepentimiento del penado y que la parte ofendida no se opone a la concesión de la gracia solicitada".

$\mathrm{N}^{\circ} 120$

Fecha de publicación: 5 de junio de 1925

Órgano o persona de la que procede la petición: El propio interesado

Delitos cometidos: Desacato y daños

Penas impuestas: Dos años, once meses y once dias de prisión correccional y multa de 1.000 pesetas, por el primero y seis meses y un día de igual prisión y 750 pesetas de multa, por el segundo

Conmutada por: Igual tiempo de destierro, a 200 kilómetros del lugar donde delinquió, dejando subsistentes las accesorias y la condena en costas

Beneficiario: Diego Martín Veloz, ex Diputado a Cortes

Motivo por el que se justifica: "Considerando las excepcionales circunstancias que concurrieron en los hechos delictivos, la buena conducta del penado y su quebrantada salud".

$\mathrm{N}^{\mathrm{o}} 121$

Fecha de publicación: 11 de junio de 1925

Órgano o persona de la que procede la petición: El propio interesado

Delito cometido: Homicidio

Pena impuesta: Doce años y un día de reclusión temporal

Conmutada por: Igual tiempo de destierro el resto de la pena que le falta por cumplir

Beneficiario: José Antonio Romero Flores

Motivo por el que se justifica: "Considerando las circunstancias que en el hecho concurrieron, el excelente comportamiento del penado y sus muestras de sincero arrepentimiento".

$\mathrm{N}^{\mathrm{o}} 122$

Fecha de publicación: 17 de junio de 1925

Órgano o persona de la que procede la petición: Soledad Cívico Martín (madre del condenado)

Delito cometido: Hurto

Pena impuesta: Seis años y un día de presidio

Se le indulta: De la tercera parte de la pena que le fue impuesta

Beneficiario: Miguel Rodríguez Cívico

Motivo por el que se justifica: "Considerando las circunstancias que concurrieron en el hecho delictivo, la buena conducta del penado y que la parte agraviada no se opone al indulto".

$\mathrm{N}^{\mathrm{o}} 123$

Fecha de publicación: 17 de junio de 1925

Órgano del que procede la petición: Audiencia de Ciudad Real

Delito cometido: Allanamiento de morada 
Pena impuesta: Tres años, seis meses y veintiún dias de prisión correccional y multa de 100 pesetas

Conmutada por: Seis meses y un día de destierro y multa de 100 pesetas

Beneficiarios: Rafael González Fernández; Rafael Fernández Castillo, Julián Vera

Pérez, Rafael Gregorio Vera Pérez, Severiano Barragán González y Gregorio Garcia Díaz

Motivo por el que se justifica: "Considerando que de la rigurosa aplicación de los preceptos legales resulta notoriamente excesiva la pena impuesta, con relación al daño causado y grado de malicia que revela".

\section{$\mathrm{N}^{\circ} 124$}

Fecha de publicación: 27 de junio de 1925

Órgano o persona de la que procede la petición: El propio interesado

Delito cometido: Disparo y lesiones

Pena impuesta: Un año, diez meses y veintiún dias de prisión correccional

Se le indulta: La mitad de la pena que le fue impuesta

Beneficiario: Eugenio Carriscajo Rojas

Motivo por el que se justifica: "Considerando las circunstancias que concurren en el presente caso, la buena conducta y arrepentimiento del penado y su falta de antecedentes penales".

\section{$\mathrm{N}^{\mathrm{o}} 125$}

Fecha de publicación: 3 de julio de 1925

Órgano o persona de la que procede la petición: El propio interesado

Delito cometido: Lesiones graves

Pena impuesta: Un año y un día de prisión correccional

Se le indulta: Del resto de la pena que le falta por cumplir

Beneficiario: José Ferrero González

Motivo por el que se justifica: "Considerando la indole del delito, las circunstancias que en el hecho concurrieron, así como la buena conducta y muestras de arrepentimiento del penado".

\section{$\mathrm{N}^{\circ} 126$}

Fecha de publicación: 3 de julio de 1925

Órgano o persona de la que procede la petición: El propio interesado

Delito cometido: Usurpación de título

Pena impuesta: Un año y un día de prisión correccional

Conmutada: La mitad de la pena que le fue impuesta

Beneficiario: Vicente Sanz Almarza

Motivo por el que se justifica: “Considerando que las partes perjudicadas no se oponen al indulto y la escasa gravedad del hecho de autos, ya que ejerció la profesión poco antes de concluir los estudios de su carrera”.

\section{$\mathrm{N}^{\mathrm{o}} 127$}

Fecha de publicación: 2 de agosto de 1925

Órgano o persona de la que procede la petición: Aquilina Martín Buitrago (esposa del condenado)

Delito cometido: Disparo de arma de fuego

Pena impuesta: Seis meses y un día de prisión correccional

Se le indulta: Del resto de la pena que le falta por cumplir 
Beneficiario: Mil Muñoz del Bosque

Motivo por el que se justifica: "Considerando que la parte agraviada no se opone al indulto, la buena conducta del penado y el tiempo que lleva de cumplimiento de su condena".

\section{$\mathrm{N}^{\mathrm{o}} 128$}

Fecha de publicación: 2 de agosto de 1925

Órgano del que procede la petición: Sala de lo Criminal del Tribunal Supremo

Delito cometido: Homicidio

Pena impuesta: Seis años y un día de presidio

Se le indulta: Del resto de la pena que le falta por cumplir

Beneficiario: José Bernal Ruiz

Motivo por el que se justifica: "Considerando que de la rigurosa aplicación de los preceptos legales resulta notoriamente excesiva la pena impuesta en relación con el grado de malicia que revela el delito y las especiales circunstancias que concurrieron en el mismo".

\section{$\mathrm{N}^{\mathrm{o}} 129$}

Fecha de publicación: 2 de agosto de 1925

Órgano o persona de la que procede la petición: La propia interesada

Delito cometido: Hurto

Pena impuesta: Cuatro años, dos meses y un día de prisión correccional

Se le indulta: Del total de la pena que le ha sido impuesta

Beneficiaria: Salustiana Carrán López

Motivo por el que se justifica: "Considerando las especiales circunstancias que concurren en el caso de que se trata y la buena conducta de la penada".

$\mathrm{N}^{\circ} 130$

Fecha de publicación: 25 de agosto de 1925

Órgano o persona de la que procede la petición: El propio interesado

Delito cometido: Excitación a la rebelión

Pena impuesta: Ocho años y un día de prisión mayor y accesorias de suspensión de cargo y derecho de sufragio

Se le indulta: De la totalidad de la pena.

Beneficiario: Pedro Chalbaud y Errazquin

Motivo por el que se justifica: "Considerando que en el presente caso concurren circunstancias de equidad y que se trata delito de carácter político cometido por medio de la Prensa".

\section{$\mathrm{N}^{\circ} 131$}

Fecha de publicación: 28 de agosto de 1925

Órgano del que procede la petición: Capitán general de la séptima Región

Delito cometido: Robo en grado de frustración

Pena impuesta: Tres años, seis meses y veintiún dias de presidio correccional Conmutada por: Seis meses de arresto mayor, quedando subsistente lo demás que determina la sentencia

Beneficiario: Marcelo Palomo Bernal, soldado del Regimiento de Infantería Segovia número 73

Motivo por el que se justifica: “Teniendo en cuenta las circunstancias especiales del caso". 
$\mathrm{N}^{\mathrm{o}} 132$

Fecha de publicación: 11 de septiembre de 1925

Órgano o persona de la que procede la petición: El propio interesado

Delito cometido: Imprudencia temeraria

Pena impuesta: Un año y un día de prisión correccional

Conmutada por: Destierro del resto de la pena que le falta por cunplir

Beneficiario: Primo de San Marcelo Villamor

Motivo por el que se justifica: "Considerando la naturaleza del delito, la buena conducta y falta de antecedentes penales del solicitante y que la parte ofendida ha otorgado su perdón".

$\mathrm{N}^{\circ} 133$

Fecha de publicación: 12 de septiembre de 1925

Órgano o persona de la que procede la petición: El propio interesado

Delito cometido: Allanamiento de morada y daños

Pena impuesta: Tres años, seis meses y veintiún días de prisión correccional y multa de 500 pesetas, por el primero, y multa de 100 pesetas por el segundo

Conmutada: La pena de privación de libertad por destierro, quedando subsistentes las multas.

Beneficiario: Angel Chena Basanta

Motivo por el que se justifica: "Considerando que ha sido perdonado por la parte perjudicada, así como la buena conducta que el penado viene observando".

\section{$\mathrm{N}^{\mathrm{o}} 134$}

Fecha de publicación: 23 de septiembre de 1925

Órgano o persona de la que procede la petición: El propio interesado

Delito cometido: Abusos deshonestos

Pena impuesta: Tres años, seis meses y veintiún dias de prisión correccional

Conmutada por: Destierro de la pena que le falta por cumplir

Beneficiario: Julio Jiménez González

Motivo por el que se justifica: "Considerando que las partes agraviadas han otorgado su perdón, así como los buenos antecedentes del penado y su intachable conducta y muestras de arrepentimiento en la prisión".

$\mathrm{N}^{\circ} 135$

Fecha de publicación: 27 de septiembre de 1925

Órgano del que procede la petición: Varias entidades y vecinos de Valencia así como el propio interesado

Delito cometido: Estafa

Pena impuesta: Un año, ocho meses y veintiún días de presidio correccional

Se le indulta: Del resto de la pena que le falta por cumplir

Beneficiario: José María Juan Garcia

Motivo por el que se justifica: "Considerando que la parte agraviada se adhiere y firma la solicitud de indulto de los vecinos de Valencia, los buenos antecedentes del penado y su conducta y arrepentimiento".

\section{$\mathrm{N}^{\circ} 136$}

Fecha de publicación: 29 de septiembre de 1925

Órgano del que procede la petición: Sala. de lo Criminal del Tribunal Supremo 
Delitos cometidos: Asesinato y parricidio

Pena impuesta: Dos penas de muerte

Conmutada por: Cadena perpetua con sus accesorias

Beneficiario: Dionisio Mínguez Martínez

Motivo por el que se justifica: "Considerando las circunstancias que concurren en el presente caso... Vengo en conmutar la del delito de parricidio por cadena perpetua con sus accesorias, quedándole también conmutada por la cadena perpetua, en virtud de lo dispuesto en Mi Real decreto de amnistía e indulto general de 4 de Julio de 1924, la otra pena de muerte que le fue impuesta por el delito de asesinato, comprendido en el artículo $3^{\circ}$ de dicha disposición general".

\section{$\mathrm{N}^{\circ} 137$}

Fecha de publicación: 21 de octubre de 1925

Órgano o persona de la que procede la petición: Miguel Serrano de la Iglesia (hermano del condenado)

Delitos cometidos: Cuatro de homicidio y dos de lesiones

Pena impuesta: Cuarenta años de reclusión temporal

Se le indulta: Del resto de las penas que le faltan por cumplir

Beneficiario: Tomás Serrano de la Iglesia

Motivo por el que se justifica: "Considerando los muchos años de privación de libertad que lleva el penado y su buena conducta y prueba de arrepentimiento".

\section{$\mathrm{N}^{\mathrm{o}} 138$}

Fecha de publicación: 21 de octubre de 1925

Órgano o personas de las que procede la petición: Los propios interesados

Delitos cometidos: Diez y siete delitos de estafa

Pena impuesta: Un año, ocho meses y veintiún días de presidio correccional y otras de arresto mayor

Se les indulta: Del resto de las penas que les falta por cumplir

Beneficiarios: Salvador Navarro Maseres y Juan Bautista Gea López

Motivo por el que se justifica: "Considerando que los perjudicados no se oponen al indulto y han sido indemnizados, y la buena conducta que vienen observando los penados".

\section{$\mathrm{N}^{\circ} 139$}

Fecha de publicación: 21 de octubre de 1925

Órgano o persona de la que procede la petición: El propio interesado

Delito cometido: Disparo de arma de fuego

Pena impuesta: Un año, ocho meses y veintiún días de prisión correccional,

Se le indulta: Del resto de la pena que le falta por cumplir

Beneficiario: Domingo Iradier Diez

Motivo por el que se justifica: "Considerando que la parte agraviada no se opone al indulto y la buena conducta y pruebas de arrepentimiento del penado".

\section{$\mathrm{N}^{\mathrm{o}} 140$}

Fecha de publicación: 21 de octubre de 1925

Órgano o persona de lal que procede la petición: El propio interesado

Delito cometido: Desacato

Pena impuesta: Un año y un día de prisión correccional y multa de 125 pesetas

Conmutada por: Destierro de la pena que le falta por cumplir 
Beneficiario: Emilio Otero Muñoz

Motivo por el que se justifica: "Considerando las circunstancias del delito, la avanzada edad del penado, su carencia de antecedentes penales $\mathrm{v}$ el tiempo que lleva de cumplimiento de condena".

$\mathrm{N}^{\circ} 141$

Fecha de publicación: 21 de octubre de 1925

Órgano o persona de la que procede la petición: El propio interesado

Delito cometido: Robo

Pena impuesta: Cuatro años, dos meses y un día de presidio correccional

Conmutada por: Destierro la mitad de la pena que le falta por cumplir

Beneficiario: Ricardo López Mesa

Motivo por el que se justifica: "Considerando que la parte agraviada presta su conformidad al indulto y la intachable conducta que viene observando el penado".

$\mathrm{N}^{\circ} 142$

Fecha de publicación: 31 de octubre de 1925

Órgano o personas de las que procede la petición: el Director y varios Profesores de la Escuela especial de Veterinaria de esta Corte así como por los padres del condenado

Delito cometido: Atentado a la Autoridad

Pena impuesta: Un año, ocho meses y veintiún dias de prisión correccional y multa de 250 pesetas

Conmutada por: Destierro del resto de la pena que le falta por cumplir

Beneficiario: Victorino Poyatos Bermejo

Motivo por el que se justifica: "Considerando las circunstancias que concurrieron en el hecho delictivo, la buena conducta del penado, sus servicios en el Ejército y el perdón de la parte ofendida".

\section{$\mathrm{N}^{\mathrm{o}} 143$}

Fecha de publicación: 31 de octubre de 1925

Órgano o persona de la que procede la petición: El propio interesado

Delito cometido: Homicidio por imprudencia temeraria

Pena impuesta: Un año y un día de prisión correccional

Conmutada por: Destierro del resto de la pena que le falta por cumplir

Beneficiario: Pedro Díaz Larrauri

Motivo por el que se justifica: "Considerando la naturaleza del hecho, la buena conducta del penado y no oponerse al indulto la parte agraviada, que ha sido indemnizada en lo posible del daño sufrido".

$\mathrm{N}^{\circ} 144$

Fecha de publicación: 31 de octubre de 1925

Órgano del que procede la petición: Audiencia de Murcia

Delito cometido: Falsedad en documento público

Pena impuesta: Seis años y un día de presidio correccional

Se le indulta: Del resto de la pena que le falta por cumplir

Beneficiario: Laureano Frías González

Motivo por el que se justifica: "Considerando que de la rigurosa aplicación de los preceptos legales resulta notoriamente excesiva la pena impuesta con relación al daño causado y grado de malicia que revela". 
$\mathrm{N}^{\circ} 145$

Fecha de publicación: 31 de octubre de 1925

Órgano del que procede la petición: Audiencia de Zaragoza

Delito cometido: Robo

Pena impuesta: Tres años, seis meses y veintiún dias de presidio correccional

Se le indultar: Del resto de la pena que le falta por cumplir

Beneficiario: Filemón Guerrero Muñoz

Motivo por el que se justifica: "Considerando que de la rigurosa aplicación de los preceptos legales resulta notoriamente excesiva la pena impuesta con relación al daño causado y grado de malicia que revela".

\section{$\mathrm{N}^{\circ} 146$}

Fecha de publicación: 31 de octubre de 1925

Órgano del que procede la petición: Audiencia de Madrid

Delito cometido: Homicidio

Pena impuesta: Seis años y un día de prisión mayo

Se le indultar: Del resto de la pena que le falta por cumplir

Beneficiario: Tomás Páramo Domínguez

Motivo por el que se justifica: "Considerando que de la rigurosa aplicación de los preceptos legales resulta notoriamente excesiva la pena impuesta con relación al daño causado y grado de malicia que revela".

\section{$\mathrm{N}^{\mathrm{o}} 147$}

Fecha de publicación: 31 de octubre de 1925

Órgano o persona de la que procede la petición: El propio interesado

Delito cometido: Contrabando

Pena impuesta: Multa de 10.125 pesetas

Conmutada por: Un mes y un día de arresto mayor (privación de. libertad que debe sufrir en sustitución de la parte de multa que le corresponde en caso de insolvencia)

Beneficiario: Gregorio Cerezo Cardaño

Motivo por el que se justifica: "Considerando las circunstancias que concurrieron en el hecho delictivo y que Gregorio Cerezo Cardaño, al parecer por insolvencia, no ha satisfecho la parte de multa que le corresponde, debiendo, por tanto, sufrir la sustitutoria personal equivalente".

\section{$\mathrm{N}^{\mathrm{o}} 148$}

Fecha de publicación: 5 de noviembre de 1925

Órgano o persona de la que procede la petición: Maria Antonia Aguirre y Olózaga (esposa del condenado)

Delitos cometidos: Negligencia y abandono de destino en campaña ("sucesos ocurridos en el territorio de Melilla en el mes de Julio de 1921")

Pena impuesta: Seis años de prisión militar correccional por primero y doce años y un dia de reclusión militar temporal por segundo

Se le concede: El indulto total "del resto de la pena que se halla extinguiendo, quedando subsistentes las accesorias que determina la parte dispositiva de la sentencia".

Beneficiario: Francisco Jiménez Arroyo, ex Coronel de Infantería

Motivo por el que se justifica: "Teniendo en cuenta las especiales circunstancias que en este caso concurren". 
$\mathrm{N}^{\mathrm{o}} 149$

Fecha de publicación: 5 de noviembre de 1925

Órgano o persona de la que procede la petición: Concepción García (esposa del condenado)

Delito cometido: No se especifica. Se alude a "los sucesos ocurridos en el territorio de Melilla en el mes de Julio de 1921".

Pena impuesta: Doce años y un día de reclusión militar temporal

Se le concede: El indulto total "del resto de la pena que se halla extinguiendo, quedando subsistentes las accesorias que determina la parte dispositiva de la sentencia”.

Beneficiario: Gustavo Domínguez Escudero ex Alférez de Infantería

Motivo por el que se justifica: "Teniendo en cuenta las especiales circunstancias que en este caso concurren".

$\mathrm{N}^{\circ} 150$

Fecha de publicación: 17 de noviembre de 1925

Órgano del que procede la petición: Audiencia de Barcelona

Delito cometido: Amenazas de muerte

Pena impuesta: Cuatro años, dos meses y un día de prisión correccional

Conmutada por: Dos años de prisión correccional

Beneficiario: Domingo Quiles Ginés

Motivo por el que se justifica: "Considerando que de la rigurosa aplicación de los preceptos legales resulta notoriamente excesiva 1a. pena impuesta en relación al daño causado y grado de malicia que revela”.

\section{$\mathrm{N}^{\circ} 151$}

Fecha de publicación: 17 de noviembre de 1925

Órgano del que procede la petición: Audiencia de Valencia

Delito cometido: Falsedad en documento público

Pena impuesta: Ocho años y un dia de presidio mayor y multa de 500 pesetas

Conmutada por: Seis años de destierro

Beneficiario: Francisco Cócera Navarro

Motivo por el que se justifica: "Considerando que de la rigurosa aplicación de los preceptos legales resulta notoriamente excesiva la pena impuesta en relación al daño causado y grado de malicia que revela".

\section{$\mathrm{N}^{\mathrm{o}} 152$}

Fecha de publicación: 17 de noviembre de 1925

Órgano o persona de la que procede la petición: El propio interesado

Delito cometido: Disparo de arma de fuego

Pena impuesta: Seis meses y un día de prisión correccional

Se le indulta: Del resto de la pena que le falta por cumplir

Beneficiario: Arsenio Martín Minguez

Motivo por el que se justifica: "Considerando las circunstancias que concurren en el presente caso, que la parte agraviada no se opone al indulto y el tiempo de cumplimiento de la condena que lleva el penado".

$\mathrm{N}^{\circ} 153$

Fecha de publicación: 17 de noviembre de 1925

Órgano del que procede la petición: Audiencia de Valladolid 
Delito cometido: Homicidio

Pena impuesta: Seis años y un día de prisión mayor

Se le indulta: Del resto de la pena que le queda por cumplir

Beneficiaria: Juana Bartolomé Andrés

Motivo por el que se justifica: "Considerando que de la rigurosa aplicación de los preceptos legales resulta notoriamente excesiva la pena impuesta en relación con el grado de malicia que revela, y considerando, asimismo, el tiempo que lleva el penado de cumplimiento de condena".

\section{$\mathrm{N}^{\mathrm{o}} 154$}

Fecha de publicación: 17 de noviembre de 1925

Órgano o persona de la que procede la petición: El propio interesado

Delito cometido: Encubridor en tres delitos de hurto

Pena impuesta: Multa de 500 pesetas

Se le indulta: Del total de la prisión sustitutoria de la multa

Beneficiario: Rafael Agudo Ayllón,

Motivo por el que se justifica: "Considerando las circunstancias que concurren en el presente caso, que la parte perjudicada no se opone al indulto, la buena conducta y falta de antecedentes penales del solicitante y que la prisión que sufre se deriva de su insolvencia".

\section{$\mathrm{N}^{\mathrm{o}} 155$}

Fecha de publicación: 18 de noviembre de 1925

Órgano del que procede la petición: Consejo Supremo de Guerra y Marina

Delito cometido: Ejecutar actos con tendencia a ofender de obra a superior de la clase de tropa en actos del servicio

Pena impuesta: Seis años y un día de prisión militar mayor

Conmutada por: Dos años de prisión militar correccional, "quedando subsistente lo demás que determina la sentencia"

Beneficiario: Rafael Moreno Rodríguez, Cabo del Tercio

Motivo por el que se justifica: "Teniendo en cuenta las circunstancias especiales del caso".

\section{$\mathrm{N}^{\circ} 156^{84}$}

Fecha de publicación: 4 de diciembre de 1925

Órgano del que procede la petición: Federico García Gómez (tío de la condenada)

Delito cometido: Lesiones

Pena impuesta: Un año y un día de prisión correccional

Se le indulta: Del resto de la pena que le falta por cumplir

Beneficiaria: Juana Gómez Rey

Motivo por el que se justifica: "Considerando las circunstancias especiales que concurren en el presente caso y que la parte agraviada se adhiere a la petición de indulto solicitado".

\section{$\mathrm{N}^{\mathrm{o}} 157$}

Fecha de publicación: 4 de diciembre de 1925

Órgano del que procede la petición: Audiencia de Valladolid

84 Formalmente se considera que el Directorio militar se extendió hasta el 3 de diciembre y estos indultos se firman el día 2 aunque no aparecen en la Gaceta hasta dos días después. 
Delito cometido: Homicidio

Pena impuesta: Catorce años, ocho meses y un día de reclusión temporal

Conmutada por: Doce años y un día de reclusión temporal

Beneficiario: Moisés Santana Orduña

Motivo por el que se justifica: "Considerando las circunstancias que produjeron el hecho delictivo, y por las que resulta en parte excesiva la pena impuesta en relación con el grado de malicia del delincuente".

\section{$\mathrm{N}^{\circ} 158$}

Fecha de publicación: 4 de diciembre de 1925

Órgano o persona de la que procede la petición: Antonio Estella Bermúdez de Castro, abogado del condenado

Delitos cometidos: Homicidio y disparo de armas

Penas impuestas: Doce años y un día de reclusión temporal, por el primero, y seis meses y un día de prisión correccional, por el segundo.

Conmutada por: Cuatro años, dos meses y un día de prisión correccional (solamente la primera).

Beneficiario: Mario Guzmán Sánchez

Motivo por el que se justifica: "Considerando las circunstancias especiales que concurren en el presente caso, las en (sic) que se produjo el hecho delictivo, los buenos antecedentes del penado y su conducta y muestras de arrepentimiento en la prisión”.

Fecha de envío / Submission date: 9/03/2020

Fecha de aceptación / Acceptance date: 28/04/2020 